\title{
Partial removal and detoxification of Malachite Green and Crystal Violet from laboratory artificially contaminated water by Pleurotus ostreatus
}

\author{
Edwin D. Morales-Álvarez ${ }^{1,2, \dagger}$, Claudia M. Rivera-Hoyos ${ }^{1, \dagger}$, Natalia González-Ogliastri ${ }^{1, \dagger}$, \\ Refugio Rodríguez-Vázquez ${ }^{3}$, Raúl A. Poutou-Piñales ${ }^{1}$, Carlos E. Daza ${ }^{4}$, \\ Aura M. Pedroza-Rodríguez ${ }^{1, *}$
}

\author{
Edited by \\ Juan Carlos Salcedo-Reyes \\ (salcedo.juan@javeriana.edu.co) \\ 1. Grupo de Biotecnología Ambiental \\ e Industrial (GBAI), Departamento de \\ Microbiología, Facultad de Ciencias. \\ Pontificia Universidad Javeriana. \\ Bogotá, D.C., Colombia. \\ 2. Departamento de Química, \\ Facultad de Ciencias Exactas y Naturales, \\ Universidad de Caldas. \\ Manizales, Caldas, Colombia. \\ 3. Departamento de Biotecnología y \\ Bioingeniería, Centro de Investigaciones \\ y Estudios Avanzados del Instituto \\ Politécnico Nacional. \\ México D.F., México. \\ 4. Departamento de Química, \\ Facultad de Ciencias, Universidad \\ Nacional de Colombia. \\ Bogotá, D.C., Colombia. \\ † All three authors contributed equally \\ in this work and should be consider as \\ first authors. \\ *apedroza@javeriana.edu.co
}

Received: 20-05-2016

Accepted: 05-10-2016

Published on line: 30-10-2016

Citation:

Morales-Álvarez ED, Rivera-Hoyos CM, González-Ogliastri N, RodríguezVázquez R, Poutou-Piñales RA, Daza CE, Pedroza-Rodríguez AM. Partial removal and detoxification of Malachite Green and Crystal Violet from laboratory artificially contaminated water by Pleurotus ostreatus, Universitas Scientiarum, 21 (3): 259-285, 2016. doi: 10.11144/Javeriana.SC21-3.prad

OPEN ACCESS

\section{Abstract}

The triphenylmethane Malachite Green (MG) and Crystal Violet (CV) dyes are cationic dyes and mix with domestic wastewater when dumped; increasing, among others, the chemical and biological oxygen demand and can cause acute toxicity at different trophic levels. Promoting the removal (decolorization) of MG and $\mathrm{CV}$, and laccase activity (54.8 \pm 8.9 and $30.6 \pm 2.9 \mathrm{UL}^{-1}$ respectively) by using P. ostreatus viable biomass needed parameters such as $\mathrm{pH}$ (4.5 and 6.0), temperature $\left(25\right.$ to $\left.30{ }^{\circ} \mathrm{C}\right)$, stirring speed $(120 \mathrm{rpm})$, percentage of inoculum $(2 \% \mathrm{v} / \mathrm{v})$, and dye concentration (20 and $\left.10 \mathrm{mg} \mathrm{L}^{-1}\right)$. In adsorption studies, it was showed that an acidic $\mathrm{pH}$ favors the adsorption of both dyes and the model of pseudo-second order describes best the phenomenon of adsorption. Finally, the germination index (GI), using Lactuca sativa seeds for the initial dyes solutions, was $<50 \%$; demonstrating its high phytotoxic effect. When dye solutions were treated with viable biomass, the GI increased, leaving open the possibility to perform future research to determine if the aqueous solutions, post-treated with $P$. ostreatus, could be used in treatments that generate less toxic water which could be used in processes that do not require potable water.

Keywords: Pleurotus ostreatus; Malachite Green; Crystal Violet; decolorization and adsorption.

\section{Introduction}

A Triphenylmethane dyes, such as Malachite Green (MG) and Crystal Violet (CV), are synthetic cationic dyes frequently used in various industries: textiles, tanneries, fish farming, cosmetics, and plastic arts. Additionally, these dyes are widely used for Gram stains and colorations for spores, etc. in many educational institutions, research centers, and hospitals. Although small volumes are used in these activities (i.e. 1-2 mL per biological sample), the annual amount can be considerably increased (up to $6 \pm 1$ liters per semester at a university that has teaching and also research activities). During laboratory practices, laboratory wastewater-containing dyes are stored in plastic containers for final disposal, allowing small amounts to seep into drains and mix with domestic wastewaters. Although in this step the dyes undergo a process of dilution, 


\section{Funding:}

This research was funded by Grants, Project ID: 00004334 (Expresión a escala de laboratorio de las lacasas recombinantes de Pleurotus ostreatus y Ganoderma lucidum), and Project ID: 00004335 (Evaluación de Ganoderma lucidum, Pleurotus ostreatus y fotocatálisis con $\mathrm{TiO}_{2} / \mathrm{CuSO}_{4}$ para la remoción de colorantes trifenilmetánicos) from Pontificia Universidad Javeriana, Bogotá, D.C. Colombia Grupo de Biotecnología Ambiental e Industrial (GBAI). The funder had no role in study design, data collection and analysis, decision to publish, or preparation of the manuscript.

Electronic supplementary material: Suppl. 1 the environmental impact is not eliminated due to the fact that triphenylmethane dyes increase the chemical oxygen demand (COD), biological oxygen demand (BOD), solids content, water color, and can cause acute toxicity at different trophic levels (Przystaś et al., 2012).

The environmental problem is increased because these dyes have a chromophore group, consisting of a central carbon (methine group) bonded to three terminal aryl groups, which may be substituted by amino or hydroxyl functional groups in the para position of the aromatic ring (Thetford 2006). Additionally, these dyes have a solubilizing group; $\mathrm{CV}$ with $\mathrm{C}^{-}$ion and $\mathrm{MG}$ an oxalate ion $\left(\mathrm{C}_{2} \mathrm{O}_{4}^{-2}\right)$. These chemical characteristics determine that triphenylmethane dyes are more resistant to biological degradation than other families of dyes and explains how biodegradation byproducts of these dyes can form intermediaries with more toxicity than the initial compound. For example, the MG and CV interact with the negatively charged cell membrane and accumulate over long periods of time causing skin irritation, liver damage, kidney failure, and have been linked to tumor formation in fishes (Oplatowska et al., 2011, Parshetti et al., 2011).

For the biological removal of triphenylmethane dyes, there have been several successful studies using aerobic and anaerobic bacteria. However, these conventional processes can have some limitations (low removal efficiency by adsorption, saturation of biomass, $\mathrm{pH}$, and temperature sensitivity, etc.). Hence why, other microorganisms that can be more efficient and tolerate to the changes that occur in the physicalchemical conditions of wastewater contaminated with dyes. In this sense, wood rotting fungi, such as $P$. ostreatus, have received great attention. These fungi degrade phenolic compounds with structural similarity to lignin (dyes). Such degradation is the result of the combination of enzymatic and non-enzymatic systems. The ligninolytic enzymes (i.e. laccase (EC 1.10.3.2), manganese peroxidase (EC 1.11.1.13), lignin peroxidase (EC 1.11.10.14), and the versatile peroxidase (EC 1.11.1.16)) participate in the degradation. Other hydrogen-producing enzymes are also involved like aryl alcohol dehydrogenase (EC 1.1.1.90) and the glyoxal oxidase (EC 1.2.3.5). These enzymatic mechanisms generate peroxide, mediated by cellobiose dehydrogenase (EC 1.1.99.18) and the quinones redox cycle. This peroxide reacts with iron salts at acidic $\mathrm{pH}$; conducting a biological Fenton process that generates highly reactive hydroxyl radicals on the triphenylmethane compounds (Dashtban et al., 2010).

Among the most studied enzymes, it is possible to found laccases, also called benzendiol: Oxygen oxidoreductases. These proteins may be dimeric or tetrameric glycoproteins and contain four copper atoms in its active site $\left(\mathrm{Cu}^{+2}\right)$. They can catalyze the oxidation of ortho and para diphenols, aminophenols, polyphenols, polyamines, lignin, dyes, and aryl diamines. This process starts upon binding oxygen or aromatic compounds to the active site, which occurs four times, and ends when the enzyme returning to a relaxed state. Additionally, water is one of the catalytic reaction's product, so it has been called a green catalyst (Rivera-Hoyos et al., 2013, Sáenz-Suárez et al., 2014, Rivera-Hoyos et al., 2015).

On the other hand, mycelia morphology of Pleurotus ostreatus (thin hyaline hyphae, long and pellets) and spore production are additional functional aspects that favor the removal of triphenylmethane dyes. The fungal wall, composed by chitin, acts 
as natural adsorbent and the spore production facilitates the development of new hyphae to form a compact mycelial network; acting at the same time as new active sites for adsorption. As a result, the fungus generates a sequential mechanism (bio adsorption/biotransformation) which potentiates the removal of the dyes in a short periods of time, supports $\mathrm{pH}$ changes and the presence of heavy metals, and can be reused in several operation cycles generating less sludge (Puentes-Cárdenas et al., 2012b, Castillo-Carvajal et al., 2013).

Thusly, the removal of CV and MG dyes was evaluated in this study; using viable biomass (VB) and nonviable biomass (NVB) of P. ostreatus to determine its relationship with the laccase activity and adsorption mechanisms. Additionally, the effect of the dyes before and after treatment with the fungal biomass by means of GI of Lactuca sativa seeds was assessed using "in vitro" assays in humid chamber and submerged camera.

\section{Materials and methods}

\section{Microorganism and culture media}

P. ostreatus was supplied by the Laboratory of Environmental and Soils Microbiology, from the Pontificia Universidad Javeriana. Strain reactivation was performed on Wheat Bran Extract agar (WBEA) for seven days at $30^{\circ} \mathrm{C}$. Production of pelletized biomass was performed by inoculating five discs of Wheat Bran Extract Agar with fungal biomass in $100 \mathrm{~mL}$ Erlenmeyer flasks with $50 \mathrm{~mL}$ of broth Wheat Bran Extract (BWBE). The cultures were incubated at $30{ }^{\circ} \mathrm{C}$ at $120 \mathrm{rpm}$ during seven days.

\section{Experimental design}

With the objective to define the best conditions to perform the removal experiments, two Plackett-Burman Experimental Designs (PBED) were conducted to evaluate the effect of the five factors at two levels each on the decolorization percentage of MG, $\mathrm{CV}$, and laccase activity (Table 1). Each experiment was carried out in triplicates using $100 \mathrm{~mL}$ Erlenmeyer flasks with $50 \mathrm{~mL}$ of minimum mineral medium supplemented accordingly with each treatment. The operating conditions were set up according to the PBED matrix; generating 36 runs (12 treatments). Wet biomass from P. ostreatus was used as the inoculum and expressed as weight percentage. At the end of the evaluation time ( $72 \mathrm{~h}$ for $\mathrm{MG}$ and $216 \mathrm{~h}$ for $\mathrm{CV}$ ), supernatants were recovered by centrifugation at $8000 \mathrm{rpm}$ during 10 minutes and the initial and final concentration were determined in $\mathrm{mg} \mathrm{L}^{-1}$ for the two dyes at $\lambda=615 \mathrm{~nm}$ and $\lambda=590 \mathrm{~nm}$ for MG and CV respectively. Decolorization percentages were calculated by following the methodology reported by Morales et al., 2016. Laccase activity was determined following the protocol reported by Tinoco et al., 2001. Manganese peroxidase (MnP) activity was determined following the protocol reported by Quevedo-Hidalgo et al., 2015.

\section{Removal experiments}

According to PBED results obtained for both dyes, $100 \mathrm{~mL}$ Erlenmeyer flasks were used with $50 \mathrm{~mL}$ of sterile Radha medium (Radha et al., 2005). Each dye was added (20 mg L ${ }^{-1} \mathrm{MG}, \mathrm{pH} 4.5$ and $10 \mathrm{mg} \mathrm{L}^{-1} \mathrm{CV}, \mathrm{pH}$ 6.0) along with $2 \%(\mathrm{w} / \mathrm{v}$ ) of viable 
Table 1. Plackett-Burman Experimental Design (PBED).

\begin{tabular}{|c|c|c|c|c|c|c|c|}
\hline \multirow{3}{*}{ 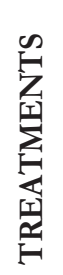 } & \multicolumn{7}{|c|}{ FACTORS } \\
\hline & $\mathbf{A}$ & B & $\mathrm{C}$ & D & $\mathbf{E}$ & $\mathbf{F}$ & G \\
\hline & $\begin{array}{c}\text { Dye } \\
\text { Concentration } \\
\mathrm{mg} \mathrm{L}^{-1}\end{array}$ & $\mathrm{pH}$ & Temperature ${ }^{\circ} \mathrm{C}$ & $\begin{array}{l}\text { Agitation } \\
\text { rpm }\end{array}$ & $\begin{array}{l}\text { Inoculum } \\
\%(v / v)\end{array}$ & $\begin{array}{l}\text { Carbon } \\
\mathrm{g} \mathrm{L}^{-1}\end{array}$ & $\begin{array}{c}\text { Nitrogen } \\
\mathrm{g} \mathrm{L}^{-1}\end{array}$ \\
\hline 1 & 20 & 6.0 & 30 & 120 & 1 & 5.0 & 0.5 \\
\hline 2 & 20 & 4.5 & 25 & 150 & 1 & 5.0 & 0.05 \\
\hline 3 & 10 & 6.0 & 30 & 120 & 2 & 5.0 & 0.05 \\
\hline 4 & 20 & 4.5 & 30 & 150 & 1 & 10.0 & 0.05 \\
\hline 5 & 20 & 6.5 & 25 & 150 & 2 & 5.0 & 0.5 \\
\hline 6 & 20 & 6.5 & 30 & 120 & 2 & 10.0 & 0.05 \\
\hline 7 & 10 & 6.5 & 30 & 150 & 1 & 10.0 & 0.5 \\
\hline 8 & 10 & 4.5 & 30 & 150 & 2 & 5.0 & 0.5 \\
\hline 9 & 10 & 4.5 & 25 & 150 & 2 & 10.0 & 0.05 \\
\hline 10 & 20 & 4.5 & 25 & 120 & 2 & 10.0 & 0.5 \\
\hline 11 & 10 & 6.5 & 25 & 120 & 1 & 10.0 & 0.5 \\
\hline 12 & 10 & 4.5 & 25 & 120 & 1 & 5.0 & 0.05 \\
\hline
\end{tabular}

and non-viable fungal biomass (VB and NVB). Inactivation of biomass after the autoclaving process (for 15 minutes at 1 atmosphere pressure, $121^{\circ} \mathrm{C}$ ) was verified by culturing the mycelium in WBEA and incubating at $30{ }^{\circ} \mathrm{C}$ for seven days. At the end of the period of incubation, no growth was observed. Both assays were performed at $120 \mathrm{rpm}$, and the evaluation time was 72 and $216 \mathrm{~h}$ for MG and CV respectively (this time was selected in function to the decoloration observed where the media was almost without dye in each case). Periodic sampling was performed to determine the percentage of decolorization, laccase activity (Tinoco et al., 2001), $\mathrm{pH}$, and reducing sugars (Miller 1959). On the other hand, some production parameters (e.g. biomass/ substrate yield) were determined $\left(\mathrm{Y}_{(\mathrm{x} / \mathrm{s})} \mathrm{g} \mathrm{g}^{-1}\right)$ and volumetric productivity $\left(\mathrm{UL}^{-1} \mathrm{~h}^{-1}\right)$, (Rivera-Hoyos et al., 2015).

\section{Adsorption studies}

For adsorption studies, a new batch of $P$. ostreatus biomass was produced in broth WBE and separated by filtration. Once inactive, the biomass was washed three times with distilled water and dried at $80{ }^{\circ} \mathrm{C}$ to constant weight. This biomass was used for adsorption tests in closed containers.

Kinetic studies for the removal of the two dyes at different $\mathrm{pH}$ values (4.0, 6.0 and $8.0 \pm 0.2$ ) were done using non-viable biomass (NVB) from P. ostreatus at a concentration of $0.5 \%$ (w/v). Removal studies were carried out in $100 \mathrm{~mL}$ shake-flasks with $50 \mathrm{~mL}$ 
of each dye (10 $\left.\mathrm{mg} \mathrm{L}^{-1}\right)$; keeping containers in the dark and constantly stirring at $120 \mathrm{rpm}$ for 180 minutes at $30^{\circ} \mathrm{C}$. To determine the residual concentration of dye (mg L$)^{-1}$ ), samples were taken at the starting point, 5, 10, 20, 30, 40, 50, 60, 90, 120, 150 and 180 minutes. Value of $q$ (amount of dye absorbed in $\mathrm{mg}$ per gram of fungal biomass added) was determined by using data from the residual dye adsorbed to the biomass (Eq. 1):

$$
q=\frac{V\left(C_{i}-C_{t}\right)}{X}
$$

Where $\mathrm{C}_{i}$ and $\mathrm{C}_{t}\left(\mathrm{mg} \mathrm{L}^{-1}\right)$ are the initial and residual $\mathrm{CV}$ or $\mathrm{MG}$ concentrations at time $t_{0}=0 \mathrm{~h}$ and $t=t(\mathrm{~h})$, respectively, $V$ is the solution volume $(\mathrm{L})$ and $X$ is the dry weight of fungal biomass (g).

Different models such as pseudo-first order, pseudo-second order, Elovich, intraparticle diffusion, and diffusion in liquid film allowed the study of adsorption dynamics of dyes by the nonviable biomass (NVB). The following parameters were calculated according to the straight-line equation described by each model: Maximum amount of dye adsorbed in mg per gram of biomass ( $q e)$, Adsorption coefficient $(k)$, Adsorption coefficient of pseudo-second order $\left(k^{2}\right)$, Initial rate adsorption $(a)$ and Desorption coefficient $(\beta)$ and the Constant of film difussion ( $(k)$ (Table 2) (Oladoja et al., 2008, Mahamadi \& Mawere 2013). The residual root means the square errors (RMSE) and correlation coefficient $\left(\mathrm{R}^{2}\right)$ of kinetic models allowed measuring the goodness of fit (Puentes et al., 2016).

\section{Determination of germination index (GI) of Lactuca sativa}

Germination tests using $L$. sativa seeds were used to assess the effect of the initial (untreated) and final dyes (treated with P. ostreatus VB or NVB) in two different methodologies. The first of them was denominated humid-chamber germination test (HCGT). For this, petri dishes of a $9 \mathrm{~cm}$ diameter and Whatman filter paper No. 3 were used. On the paper, $4 \mathrm{~mL}$ of each sample were added (100, 75, 50 and $25 \% \mathrm{v} / \mathrm{v}$ ) and 25 seeds of $L$. sativa of similar sizes (Celis et al., 2006). The boxes were protected

Table 2. Linearized adsorption kinetics models.

\begin{tabular}{|c|c|c|c|}
\hline Kinetic Models & Equations & & References \\
\hline Pseudo first-order & $\ln (q e-q)=\ln q e-k t$ & (2) & \\
\hline Pseudo second-order & $\frac{t}{q}=\frac{1}{\left(k_{2} q e^{2}\right)}+\frac{1}{q e} t$ & (3) & $\begin{array}{c}\text { (Oladoja et al., 2008, } \\
\text { Mahamadi \& Mawere 2013) }\end{array}$ \\
\hline Elovich & $q=\beta \ln (\alpha \beta)+\beta \ln (t)$ & (4) & \\
\hline $\begin{array}{l}\text { Intraparticle } \\
\text { diffusion }\end{array}$ & $q=k t^{0.5}$ & (5) & \\
\hline
\end{tabular}


with aluminum foil and stored for five days at $22 \pm 2{ }^{\circ} \mathrm{C}$. The second technique consisted of placing the same number of seeds in $4 \mathrm{~mL}$ of solution (controls and treatments) maintained under constant agitation of $100 \mathrm{rpm}$ at $22 \pm 2{ }^{\circ} \mathrm{C}$ for five days; this methodology was called Submerged Germination Test (SGT). The controls used were $\mathrm{ZnSO}_{4}(0.001 \mathrm{M})$ as positive control and distilled water as negative control. In both, 25 seeds were placed under the same conditions for each test. The response variable is the percentage of GI, which was determined following the methodology reported by Zucconi et al. (1985) and calculated with equation 6:

$$
\mathrm{GI}=\frac{G * L}{G c * L C} * 100
$$

Where: GI is the germination index (\%), $G$ is the average number of germinated seeds in the analyzed sample, $G c$ is the average number of germinated seeds in the negative control, $L$ is the average length of the radicle in the sample $(\mathrm{mm})$, and $L c$ is the average length of the radicle in the negative control. When GI values are less than $50 \%$, it is considered that the substance generates high phytotoxicity on the plant model (Emino \& Warman 2004).

\section{Statistical analysis}

Design Expert $9.0^{\circledR}$ software allowed data variance and regression analysis for the PBED. SAS $9.0^{\circledR}$ software allowed mean comparison between treatments. A confidence interval of $95 \%$ (alpha $=0.05$ ) was used.

A means comparison for removal kinetics with VB and NVB was made at the end of each kinetics using a Tukey test with a confidence interval of $95 \%$. Additionally, SAS software version $9.0^{\circledR}$ allowed correlation analysis between the percentage of decolorization and laccase activity.

\section{Results and Discussion}

\section{Plackett-Burman Experimental Design}

Table 3 and Figures 1 A, B, C, and $\mathbf{D}$ show the results of PBED for both dyes and laccase activity. Regarding the $\mathrm{MG}$, the model for decolorization showed an $\mathrm{R}^{2}$ of 0.78 and laccase activity showed an $\mathrm{R}^{2}$ of 0.90 demonstrating that only laccase activity showed high correlation between predicted and observed values with adequate precision values of 8.6. For laccase activity, the factors with significant influence were $\mathrm{b}$, c, and $\mathrm{d}(\mathrm{pH}$, temperature and stirring speed) with p values equal to: 0.0386, 0.0193, and 0.0353 respectively. Regarding the percentage of decolorization, none of the factors had a significant effect over this variable $(p>0.05)$ (Figure 1A). According to the comparison of means between treatments for laccase, significant differences were observed ( $\mathrm{p}<0.0001): \mathrm{T}_{10}, \mathrm{~T}_{11}$ and $\mathrm{T}_{3}$ the treatments that showed higher volumetric activity with values of $54.8 \pm 8.9,49.7 \pm 2.8$ and $42.7 \pm 1.7 \mathrm{UL}^{-1}$ respectively (Figure 1B). For these treatments, the decolorization at the third day of evaluation was $98.1 \pm 0.04,96.2 \pm 0.1$ and $96.3 \pm 0.1 \%$ respectively. Under the selected experimental conditions for this study, the removal experiments with MG dye were made using 
A

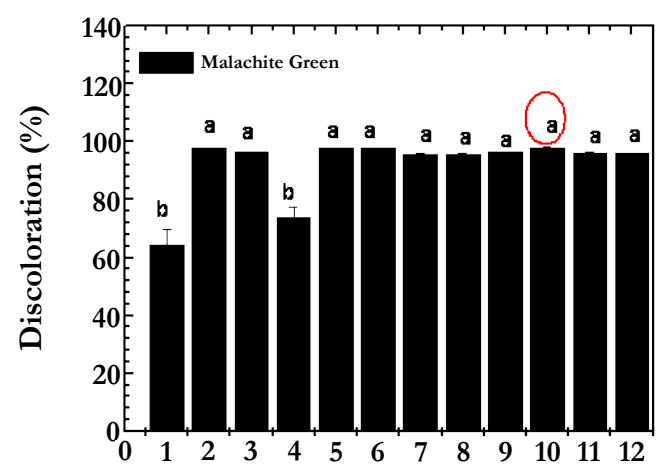

B

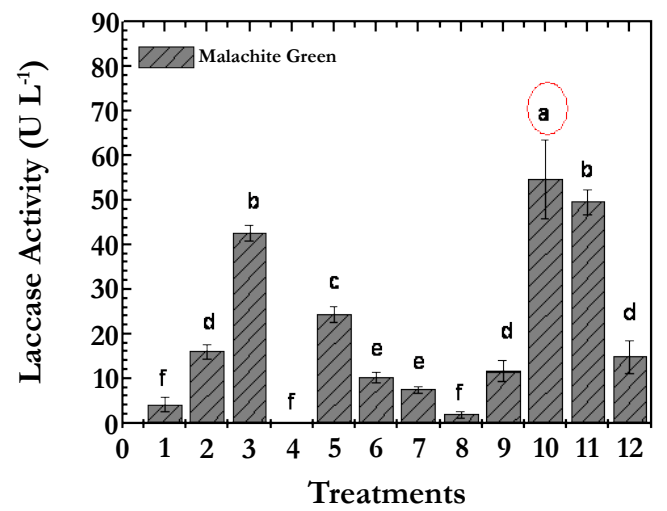

C

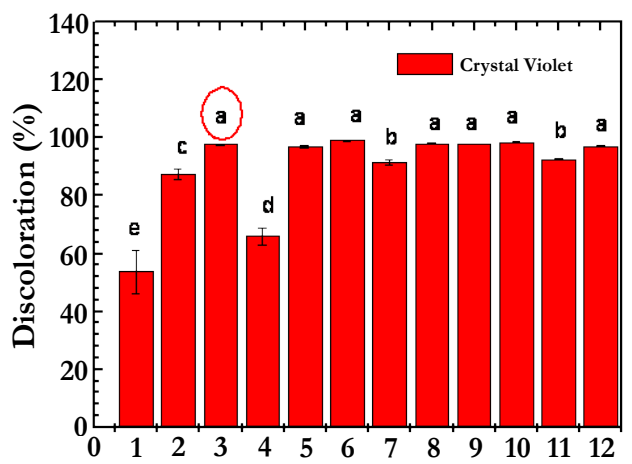

D

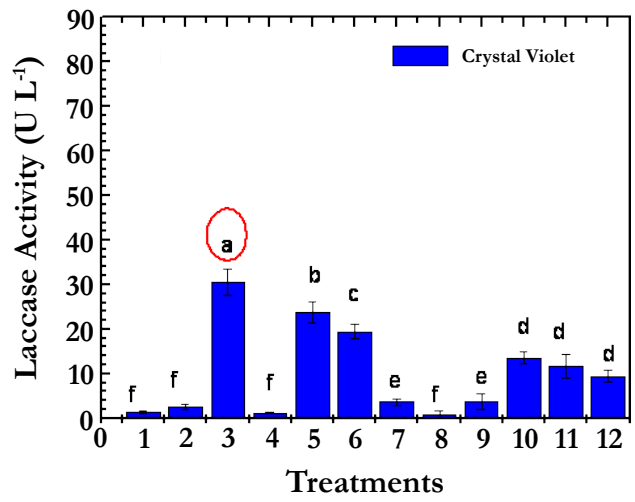

Fig. 1. Evaluated treatments in Plackett-Burman Experimental Design (PBED). (A). Decolorization percentage for MG. (B) Laccase activity for MG. (C) Decolorization percentage for CV. (D). Laccase activity for $\mathrm{CV}$. The letters a, b, c, d, e, and $\mathrm{f}$ represent the homogeneous groups obtained with the Tukey assay where a (circled in red) belongs to the treatments with higher laccases activity and decolorization percentage of $\mathrm{MG}$ and $\mathrm{CV}$, followed by b, c, d, e, and $\mathrm{f}$ in order.

the combination of factors generated for $\mathrm{T}_{10}\left(20 \mathrm{mg} \mathrm{L}^{-1}\right.$ de $\mathrm{MG}, \mathrm{pH} 4.5$, temperature $25^{\circ} \mathrm{C}$, agitation $120 \mathrm{rpm}$, inoculum $2 \% \mathrm{w} / \mathrm{v}, 10 \mathrm{~g} \mathrm{~L}^{-1}$ of glucose, and $0.5 \mathrm{~g} \mathrm{~L}^{-1} \mathrm{NH}_{4} \mathrm{Cl}$ ).

The results presented for CV showed best fit with $\mathrm{R}^{2}$ values of 0.82 and 0.95 for the percentage of decolorization and laccase activity. Moreover, the adequate precision was 4.65 and 35.04 respectively. Regarding the laccase activity for CVD, all factors had a significant effect on this variable (Table 3); being the most influential factors c, d, $\mathrm{e}$, and a (temperature, stirring speed, percentage of inoculum, and dye concentration) with p values equal to 0.0001 ( $c$ and d), 0.0002 (e) and 0005 (a). The percentage of decolorization was not significantly affected by any of the factors $(p>0.05)$. According with the means comparison between treatments for enzymatic activity, the best were: $T_{3}, T_{5}$, and $T_{6}$ with decolorization percentages of $97.1 \pm 0.2\left(T_{3}\right), 9$ $6.8 \pm 0.4\left(\mathrm{~T}_{5}\right)$, and $98.3 \pm 0.05\left(\mathrm{~T}_{6}\right)$ at five days (Figure 1C). By getting similar decolorization for all three treatments, $\mathrm{T}_{3}$ was then established as the standard treatment with the highest laccase activity $\left(30.6 \pm 2.9 \mathrm{UL}^{-1}\right)$. Removal experiments were then carried out using $10 \mathrm{mg} \mathrm{L}^{-1} \mathrm{CV}, \mathrm{pH}$ 6.0, temperature $30^{\circ} \mathrm{C}, 120 \mathrm{rpm}$, agitation, inoculum $2 \%$ (w/v), $5.0 \mathrm{~g} \mathrm{~L}^{-1}$ glucose, and $0.05 \mathrm{~g} \mathrm{~L}^{-1} \mathrm{NH}_{4} \mathrm{Cl}$ (Figure 1D).

The reasons why the temperature and stirring speed were common factors for the two dyes that favored laccase's activity might be related with various aspects. Regarding 
Table 3. ANOVA of Plackett-Burman Experimental Design for Malachite Green and Crystal Violet dyes.

\section{MALACHITE GREEN DYE}

Decolorization Percentage (\%)

Laccase Volumetric activity $\left(\mathrm{UL}^{-1}\right)$

\begin{tabular}{cccccccc}
\hline Factor & Valor F & Prob $>$ f & CR & Factor & Valor F & Prob >f & CR \\
Model & 2.10 & 0.2474 & 92.19 & Model & 5.68 & 0.0562 & 0.99 \\
A & 2.44 & 0.1934 & -3.82 & $\mathbf{a}$ & 1.53 & 0.2837 & -0.12 \\
B & 3.93 & 0.1186 & 4.85 & $\mathbf{b}$ & 9.21 & 0.0386 & 0.31 \\
C & 4.02 & 0.1155 & -4.90 & $\mathbf{c}$ & 14.37 & 0.0193 & -0.38 \\
D & 0.083 & 0.7879 & 0.70 & $\mathbf{d}$ & 9.78 & 0.0353 & -0.32 \\
E & 3.98 & 0.1168 & 4.88 & $\mathbf{e}$ & 3.58 & 0.1315 & 0.19 \\
F & 0.11 & 0.7612 & 0.80 & $\mathbf{f}$ & 0.27 & 0.6287 & -0.053 \\
G & 0.13 & 0.07413 & -0.87 & $\mathbf{g}$ & 1.05 & 0.3630 & 0.10 \\
Residual & & 0.7413 & & Residual & 0.12 & & \\
Cor T & 1340.57 & & & Cor T & & & \\
$\mathbf{R}^{2}$ & 0.78 & & & $\mathbf{R}^{2}$ & 0.91 & & \\
$\begin{array}{c}\text { Adeq. } \\
\text { Precision }\end{array}$ & 4.616 & & Adeq. & 8.637 & &
\end{tabular}

\section{CRYSTAL VIOLET DYE}

Decolorization Percentage (\%)

Laccase Volumetric activity (UL $\left.{ }^{-1}\right)$

\begin{tabular}{|c|c|c|c|c|c|c|c|}
\hline Factor & Valor $F$ & Prob $>f$ & CR & Factor & Valor F & Prob $>f$ & CR \\
\hline Model & 2.64 & 0.1826 & 8.74 & Model & 117.10 & 0.0002 & 1.28 \\
\hline A & 3.88 & 0.1200 & -0.90 & A & 101.66 & 0.0005 & -0.31 \\
\hline B & 3.99 & 0.1164 & 0.91 & B & 12.42 & 0.0244 & 0.11 \\
\hline C & 5.22 & 0.049 & -1.05 & $\mathrm{C}$ & 207.38 & 0.0001 & -0.44 \\
\hline D & 0.014 & 0.9109 & -0.054 & D & 237.92 & 0.0001 & -0.47 \\
\hline $\mathrm{E}$ & 5.33 & 0.05 & 1.06 & E & 195.21 & 0.0002 & 0.43 \\
\hline F & $1.422 \mathrm{E}-003$ & 0.9717 & -0.017 & F & 43.00 & 0.0028 & -0.20 \\
\hline G & 0.031 & 0.8683 & -0.081 & G & 22.09 & 0.0093 & -0.14 \\
\hline Residual & 10.04 & & & Residual & 0.045 & & \\
\hline Cor T & 56.43 & & & Cor $\mathrm{T}$ & 9.20 & & \\
\hline $\mathbf{R}^{2}$ & 0.82 & & & $\mathbf{R}^{2}$ & 0.95 & & \\
\hline $\begin{array}{c}\text { Adeq. } \\
\text { Precision }\end{array}$ & 4.65 & & & $\begin{array}{c}\text { Adeq. } \\
\text { Precision }\end{array}$ & 35.04 & & \\
\hline
\end{tabular}


temperature, the increase in this factor may promote the growth of the fungal biomass and the enzymatic reaction rate (Patel \& Gupte 2016). By raising the amount of biomass, the adsorption to the fungal biomass phenomena could benefit without losing the wall integrity. On the other hand, at higher temperatures, the diffusion rate of the dyes can be increased by a decrease in wall thickness; making the resistance to mass transfer smaller. Several authors (Aravindan et al., 2012; Puentes-Cardenas et al., 2012a; Puentes-Cardenas et al., 2012b) have reported this effect. Additionally, the stirring speed promotes the transfer of oxygen from the aqueous medium to the biomass; therefore preventing the formation of anaerobic zones inside of the pellets or microaerophilic zones, which could affect the growth and availability of molecular oxygen as acceptor for subtracted electrons by the catalytic action of the laccase enzyme (Zhang \& Zhang 2015).

\section{Removal experiments for viable and non-viable biomass}

\section{Decolorization for Crystal Violet and Malachite Green}

Percentages of decolorization for the two dyes with VB were gradually increasing from the first sampling intervals and were significantly higher than those obtained with the NLB ( $p<0.0001)$, reaching values of $98.2 \pm 0.6$ and $98.2 \pm 0.1 \%$ for MG and $\mathrm{CV}$ at 72 and $216 \mathrm{~h}$ respectively. The final percentages were very similar for MG and CV. However, the comparison of means between sampling times determined that the maximum removal time for MG was obtained at 72 hours; being significantly less than for $\mathrm{CV}$, since this dye needed between 120 and 216 hours to achieve a range of decolorization between 96 and $98 \%(\mathrm{p}<0.0001)$. Regarding adsorptive decolorization $(\mathrm{NVB})$, the percentages were $49.5 \pm 2.9$ and $45 \pm 1.9$ for MG and $\mathrm{CV}$ at 72 and 216 h respectively (Figure 2 A, B).

The highest response obtained with LB was due to two mechanisms that acts in a sequential manner. Initially, both dyes get adsorbed to the fungal wall through processes of physical/chemical type that are not associated with the metabolism of $P$. ostreatus and are strongly influenced by the $\mathrm{pH}$, the dye concentration, temperature, and stirring speed (Puentes-Cardenas et al., 2012a; Puentes-Cardenas et al., 2012b; Castillo-Carvajal et al., 2013). Subsequently, extracellular enzymes such as Laccase and $\mathrm{MnP}$, among others, could modify the dyes. This transformation involves chemical alteration of the chromophore groups, which act as potential electron donors, generating changes in the absorption spectrum of both dyes (Casas et al., 2009).

Furthermore, the differences observed between dyes are related to the chemical structure of each one; to have complete decolorization of $\mathrm{CV}$, demethylation of three groups dimethyl is required (considered as chromophore groups), and for MG only two demethylations must be carried out. It is believed that laccase carries out these demethylations; therefore, an increase in enzyme activity and decolorization are simultaneous (Vasdev, 2011). Other authors (Lyra et al., 2009; Kang et al., 2014) have reported the effect of this type and a number of chemical substituents attached to the aromatic rings of the dyes on the capacity of decolorization with ligninolytic fungus. In their studies, they determined that dyes with more substitutions need longer processes and may slow the growing speed of fungi when used at very high concentrations. 
A
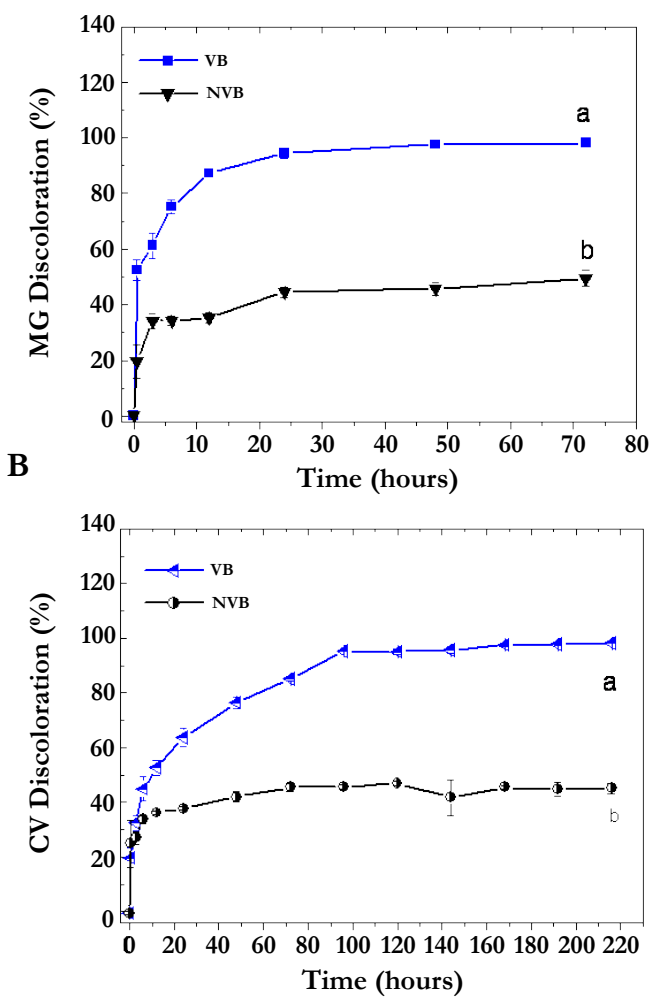

C
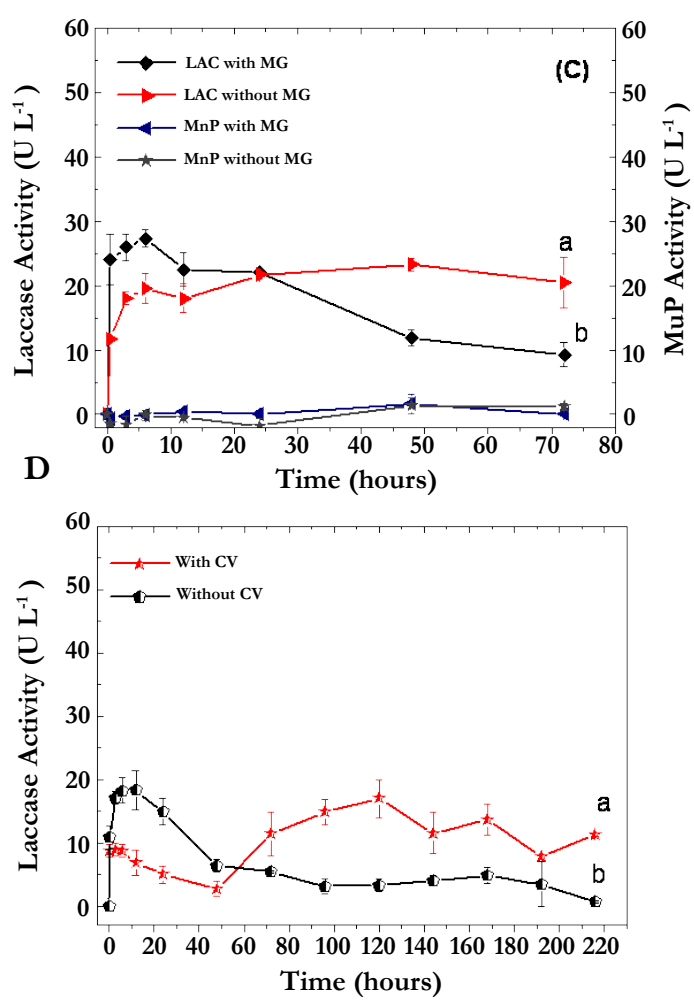

Fig. 2. Kinetics of removal under operating conditions selected with the Plackett-Burman design. (A) Decolorization of MG with VB and NVB. (B) Decolorization of CV with VB and NVB. (C) Laccase and manganese peroxidase activity in presence and absence of MG. (D) Laccase activity in presence and absence of $\mathrm{CV}$ (manganese peroxidase was not detected in presence of CV). The letters a and $\mathrm{b}$ represent the heterogeneous groups obtained with the Tukey test where the letter a, corresponds to the best treatment followed by the letter $b$. The bars represent the standard deviation of the average of three replicates.

\section{Enzymatic activities, $\mathrm{pH}$ and glucose consumption}

Figure $2 \mathrm{C}$, and $2 \mathrm{D}$ show results for Laccase and $\mathrm{MnP}$ enzymes in the presence and absence of colorants. Regarding laccase, it is possibly that activity was induced by the presence of the two dyes, showing a tendency to prolong for longer time. Laccase's activity was quantified in the absence of the two dyes and is higher in the first sampling intervals, contrasting with the fact that at the end of the kinetics, its activity has decreased in $20 \%$. Enzyme activity was higher in the presence of MG $\left(20.5 \pm 3.9 \mathrm{UL}^{-1}\right.$ at $\left.72 \mathrm{~h}\right)$ than in $\mathrm{CV}\left(17.02 \pm 2.3 \mathrm{UL}^{-1}\right.$ to $\left.120 \mathrm{~h}\right)$ confirming the differences of structural complexity between $\mathrm{MG}$ and $\mathrm{CV}$.

Additionally, the high $\mathrm{C} / \mathrm{N}$ ratio in the media with dye (Rhada Medium and dyes) could be another determining factor for higher enzymatic activity in the media without dye since fungi as $P$. ostreatus produce higher amounts of enzymes under ligninolytic conditions (high $\mathrm{C} / \mathrm{N}$ ratios). Similar results were reported by PedrozaRodríguez \& Rodríguez-Vázquez (2013). They showed that at low concentrations of nitrogen, ligninolytic enzymes increase significantly compared to a condition in which the nitrogen concentration is high and from organic nature, such as peptone or 
yeast extract. Also, the presence of aromatic compounds such as colorants and liquid waste from the paper industry tend to have high $\mathrm{C} / \mathrm{N}$ ratio at the expense of a type of carbon difficult to degrade.

$\mathrm{MnP}$ activity was only detected in the kinetics with $\mathrm{MG}$ at 12 hours and was lower than the laccase activity (Figure 2D) demonstrating that this enzyme was not primarily responsible for the decolorization because it has no activity on the $\mathrm{CH} 3$ groups acting as chromophores. Probably $\mathrm{MnP}$ acted on the demethylated aromatic rings after laccase activity. Our results are consistent with those reported by Dashtban et al, (2010). In their article, Dashtban et al proposed that peroxidases, such as $\mathrm{MnP}$, can act on simple phenolic rings and dyes provided that hydrogen peroxide, $\mathrm{Mn}^{+2}$, and an organic acid are present for them to act as a natural chelator of $\mathrm{Mn}^{+3}$ oxidized by the enzyme.

In the kinetics with $\mathrm{MG}$, a low $\mathrm{MnP}$ activity was detected. $\mathrm{MnP}$ activity was not detected in the kinetics with CV. It was probably due to compounds with three carbon atoms in their structure (e.g. oxalic acid, malonate, and acetate). These compounds that could have acted as chelators of $\mathrm{Mn}^{+3}$ and promoted the oxidation of dyes to form free radicals might have been formed from the glucose metabolism and in connection with the tricarboxylic acid cycle. Moreover, the fungus may oxidize glucose through the glyoxal oxidase enzyme (EC 1.2.3.5) causing the reaction product hydrogen peroxide that plays an important role as a co-factor for $\mathrm{MnP}$ enzyme.

The combined action of the two enzymes may facilitate the process of partial mineralization of dyes because the substitutions $\mathrm{CH}_{3}$ groups (ortho, meta, and para) are removed from the aromatic ring to generate unstable free radicals ultimately leading to the opening of the aromatic rings, the formation of intermediates of 3 carbons, and entrance to the Krebs cycle.

The difference between decolorization and enzymatic activities was evident when performing the correlation analysis in which significant positive correlations $(p<0.05)$ between the percentage of decolorization and laccase activity $(r=0.95)$ were obtained. In contrast, the correlation between decolorization and $\mathrm{MnP}$ activity was negative and non-significant $(\mathrm{p}>0.05, \mathrm{r}=-0.23)$.

In this sense, it is clear that the enzymatic activity changes according to the dye used even if they are from the same family. Kang et al. (2014) studied the growth and decolorization of 12 ligninolytic fungi using MG and CV as colorants model. As in our study, the authors observed that not all fungi could grow in CV and the decolorization was more efficient in MG. They also demonstrated that the laccase activity is quantifiable from the first sampling intervals and gradually increases until reaching values close to $38 \mathrm{U} \mathrm{mL}^{-1}$; however, at a very high concentration of dyes, an inhibition of growth and $100 \%$ decrease of the laccase activity was observed. A similar result was reported by Morales-Álvarez et al. (2016) when they evaluated the effect of increasing concentrations of MG on the radial growth of G. lucidum. They found that at concentrations ranging between 10 and $50 \mathrm{mg} \mathrm{L}^{-1}$, the growth of the fungi decreases when cultured in a chemically defined medium as agar Rhada. On the contrary, in complex media and with organic nitrogen, the concentration of the dye does not have such a marked effect. 
Other results supporting differences in enzymatic activities in the presence and absence of dyes are the production parameters (Table 4). Regarding the formed biomass and glucose consumption associated with yield $\mathrm{Y}_{(\mathrm{x} / \mathrm{s})}$, a higher value appears when $P$. ostreatus was not in contact with the dye; showing that although the fungus tolerated and discolor the two compounds, these could affect the primary metabolism of the same without being inhibitory. Furthermore, when analyzing the results associated with the volumetric activity and productivity at 72 and 216 hours, both dyes increase enzymatic activity when compared with the experiments in the absence of the dye; possibly by the induction that these exert on the laccase enzyme. In terms of productivity for the $\mathrm{CV}$, calculations at 72 and 216 hours allowed to observe the differences and to make the comparison with the MG. According to the results in the presence of $\mathrm{CV}$, productivity was lower at 216 hours and increased from 0.052 to $0.159 \mathrm{UL}^{-1} \mathrm{~h}^{-1}$ when the analysis was carried out at $72 \mathrm{~h}$. In the absence of dyes, the results were lower for both 72 and $216 \mathrm{~h}\left(0.075\right.$ and $0.0029 \mathrm{UL}^{-1} \mathrm{~h}^{-1}$ respectively). If these results are related to the percentage of decolorization, removal kinetics for CV could be successful in just $72 \mathrm{~h}$; saving $144 \mathrm{~h}$ in processing time (Ma et al., 2014).

Regarding the MG, the enzymatic activity and productivity were higher in the presence of the dye than CV (Table 4). The percentages of decolorization at 72 hours exceeded $90 \%$. Obtaining high percentages of removal in short periods of time is a very desirable factor when working with white rot fungi since executing scaling of processes where retention times are short is best to be able to treat larger wastewater volumes. Therefore, these unconventional systems could become competitive if compared to biological systems using aerobic or anaerobic bacteria (Hai et al., 2013, Ma et al., 2014).

Table 4. Kinetics parameters for Pleurotus ostreatus under different nutritional conditions. * Parameters related to biomass, glucose yields, and volumetric activity were calculated at 72 hours for MG and 216h for CV. Data presented in the table are the average of three replicates.

\begin{tabular}{|c|c|c|c|c|}
\hline Parameters & $\begin{array}{l}\text { P. ostreatus } \\
\text { With MG } \\
\text { at } 10 \mathrm{mg} \mathrm{L}^{-1} \\
\text { of Glucose } \\
\text { and } 0.5 \mathrm{~g} \mathrm{~L}^{-1} \\
\text { Ammonium }\end{array}$ & $\begin{array}{l}\text { P. ostreatus } \\
\text { Without MG } \\
\text { at } 10 \mathrm{mg} \mathrm{L}^{-1} \\
\text { of Glucose } \\
\text { and } 0.05 \mathrm{~g} \mathrm{~L}^{-1} \\
\text { Ammonium }\end{array}$ & $\begin{array}{l}\text { P. ostreatus } \\
\text { With CV at } \\
5.0 \mathrm{mg} \mathrm{L}^{-1} \\
\text { of Glucose } \\
\text { and } 0.05 \mathrm{~g} \mathrm{~L}^{-1} \\
\text { Ammonium }\end{array}$ & $\begin{array}{l}\text { P. ostreatus } \\
\text { Without CV } \\
\text { at } 5.0 \mathrm{mg} \mathrm{L}^{-1} \\
\text { of Glucose } \\
\text { and } 0.05 \mathrm{~g} \mathrm{~L}^{-1} \\
\text { Ammonium }\end{array}$ \\
\hline Final $\mathrm{pH}$ & $6.02 \pm 0.03$ & $5.77 \pm 0.03$ & $5.55 \pm 0.05$ & $5.40 \pm 0.02$ \\
\hline Biomass $\left(\mathrm{g} \mathrm{L}^{-1}\right)$ & $0.043 \pm 0.002$ & $0.068 \pm 0.013$ & $0.106 \pm 0.012$ & $0.167 \pm 0.012$ \\
\hline $\begin{array}{l}\text { Glucose } \\
\text { consumption } \\
\left(\mathrm{g} \mathrm{L}^{-1}\right)\end{array}$ & $0.54 \pm 0.02$ & $0.76 \pm 0.02$ & $1.45 \pm 0.07$ & $1.58 \pm 0.22$ \\
\hline $\begin{array}{l}Y_{(x / s)} \\
\left(g g^{-1}\right)\end{array}$ & $0.0802 \pm 0.003$ & $0.0895 \pm 0.001$ & $0.070 \pm 0.002$ & $0.106 \pm 0.02$ \\
\hline $\begin{array}{l}\text { Volumetric } \\
\text { activity }\left(\mathrm{UL}^{-1}\right)\end{array}$ & $20.5 \pm 3.9$ & $9.3 \pm 1.9$ & $11.3 \pm 0.2$ & $0.64 \pm 0.3$ \\
\hline $\begin{array}{l}\mathbf{P}_{\text {(Enzyme) }}\left(\mathrm{UL}^{-1} \mathbf{h}^{-1}\right) \\
(\text { at } 72 \mathrm{~h})\end{array}$ & $0.28 \pm 0.03$ & $0.13 \pm 0.01$ & $0.16 \pm 0.002$ & $0.08 \pm 0.01$ \\
\hline $\begin{array}{l}\mathbf{P}_{\text {(Enzyme) }}\left(\mathrm{UL}^{-1} \mathrm{~h}^{-1}\right) \\
(\text { at } 216 \mathrm{~h})\end{array}$ & $\mathrm{ND}$ & $\mathrm{ND}$ & $0.052 \pm 0.003$ & $0.003 \pm 0.001$ \\
\hline
\end{tabular}


Regarding glucose consumption, it was observed that in the experiments with dyes, $P$. ostreatus was able to perform the remotion using low glucose concentrations $\left(<5 \mathrm{~g} \mathrm{~L}^{-1}\right)$ which could be used as co-substrate to then use dyes as a more complex carbon source. These results are favorable considering the possibilities for scaling the process, as it would not be necessary to supplement the industrial effluent with high concentrations of glucose.

On the other hand, a reduction on the $\mathrm{pH}$ was evidenced, which could be related with the production of some organic acids that are product of metabolism of sugars and thereof dyes. This decrease would not affect enzyme activity as it has been shown that both the laccase and peroxidases are active at low pHs greater than 3.0. Additionally, this drop in $\mathrm{pH}$ could also favor the removal of dye by adsorption to the fungal biomass, as seen later in the adsorption studies in function of $\mathrm{pHs}$.

\section{Adsorption studies}

\section{Effect of $\mathrm{pH}$ on the adsorption of MG and $\mathrm{CV}$}

When obtaining high removal percentages using VB, a complementary study to model the phenomenon of adsorption of the dye to the fungal biomass was necessary. It was observed that the dyes concentration in the two compounds were rapidly adsorbed from the first minutes of contact and reached equilibrium at 60 minutes. The effect of $\mathrm{pH}$ and the type of dye showed significant differences: with MG $(\mathrm{p}<0.0001)$ (Figure 3A) a pH 4.0 allowed the most adsorption, followed by the $\mathrm{pH}$ of 6.0 and 8.0; and with $\mathrm{CV}$, adsorption at different $\mathrm{pHs}$ was also significant $(\mathrm{p}<0.0001)$; However, at $\mathrm{pH} 4.0$ and 6.0 adsorption was similar $(\mathrm{p}>0.0001)$ (Figure 3B).

A

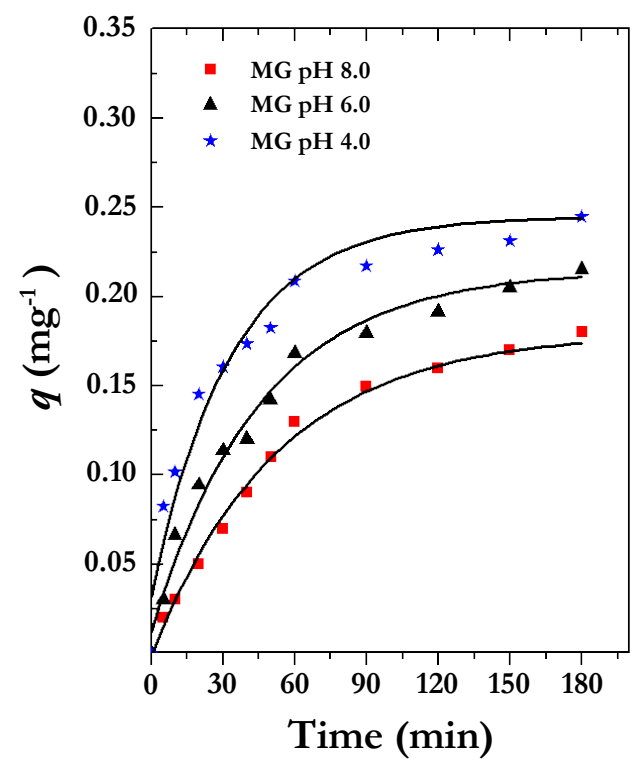

B

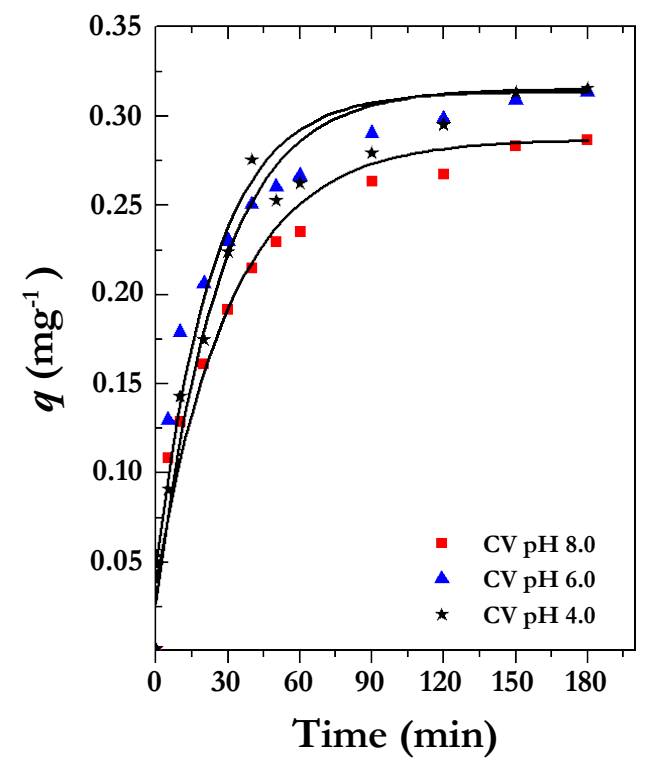

Fig. 3. $q$ value versus time at different pHs. (A) Malachite Green, MG. (B) Crystal violet, CV. The letters represent the heterogeneous groups obtained with the Tukey test where the letter a corresponds to the best adsorption $\mathrm{pH}$ followed by the letters $\mathrm{b}$ and $\mathrm{c}$. The bars represent the standard deviation of the average of three replicates. 
The $\mathrm{pH}$ is an important factor for dye removal because it can increase or decrease the adsorption capacity of the adsorbent (fungal biomass). Given that both the $\mathrm{MG}$ and the $\mathrm{CV}$ are cationic dyes, increased adsorption was due to increasing $\mathrm{pH}$ because the negative charges of biomass should attract positive charges in the dye (Cheng et al., 2008, Sun et al., 2008). However, the results obtained showed that it is possible to obtain greater adsorption at lower $\mathrm{pH}$ which is supported by the interaction of three factors. In the first instance, the $\mathrm{pK}$ value for $\mathrm{MG}$ and $\mathrm{CV}$ are 6.9 and 8.6 respectively (Fischer et al., 2011, https://pubchem.ncbi.nlm.nih. gov/compound/Crystal_violet\#section=Top). The pHs 4.0 and 6.0 are under the $\mathrm{pK}$ values in which the surface of the biomass does not have charge (i.e neutral). In addition, the adsorption could be happening because of interactions such as hydrogen bonds and Van der Waals forces (Chergui et al., 2009). Secondly, cationic dyes could act by chemisorption or by the formation of non ionic chemical complexes with uncharged ligands; which could favor the formation of ionic pairs that alter the electrostatic repulsion and favor adsorption (Kaushik \& Malik 2009). Finally, inactivation of fungal biomass increases its porosity; the contact surface and the exposure of the active sites that were potential binding sites for the dyes increase (Abdallah \& Taha 2012).

Morales-Alvarez et al. (2016) reported a similar result. In their work, adsorption studies for MG were performed using Ganoderma lucidum non-living biomass (NLB) and they obtained higher adsorbed concentrations per gram of biomass than those presented in this paper. They also showed that most adsorption occurred at acidic $\mathrm{pH}$, potentially because of the thickness of the fungus wall of G. lucidum wall and how it produces a large amount of exopolysaccharides that become binding sites for dyes.

\section{Adsorption kinetics}

Using the equations of the straight lines obtained when adjusting the data to models of pseudo-first order and pseudo-second order, the values of $k, k^{2}$, and qe were found. These values correspond with the adsorption constant and the maximum value of dye adsorbed per gram of biomass used. The equations of the intraparticle diffusion and diffusion in film models allowed us to find $K$ (constant of intraparticle diffusion and in film). The Elovich model allowed us to find the values of $\alpha$ and $\beta$ corresponding to the initial rate of adsorption and the desorption constant (Table 5), (Sahmoune \& Ouazene 2012).

According to the values of $\mathrm{R}^{2}$ represented in Table 5, the model describing the adsorption for MG at acidic $\mathrm{pHs}$ and the $\mathrm{CV}$ in the three $\mathrm{pHs}$ was of pseudo-secondorder: with values of $\mathrm{R}^{2}$ superior to 0.99 , low RMSE (A smaller RMSE value indicates a better curve fitting) and the linearity of the data was demonstrated in Figure 4A, B. However, for the MG at $\mathrm{pH}$ 8.0, the model of pseudo-second-order does not describe properly the adsorption $\left(\mathrm{R}^{2}\right.$ value of 0.9751 , RMSE 0.0865 , and the data presented in Figure 4A have no linearity). These results indicate that basic $\mathrm{pH}$ affects adsorption; maybe related to the $\mathrm{pK}$ of the $\mathrm{MG}$ (possibly low value). On the other hand, $\mathrm{MG}$ was not sensitive to $\mathrm{pH}$ changes as when performing $\mathrm{UV} /$ Vis spectrum. At $\mathrm{pH} 3.0$, there was no change and only at $\mathrm{pH} 8.0$ a lower extinction coefficient was evidenced (data not shown). 


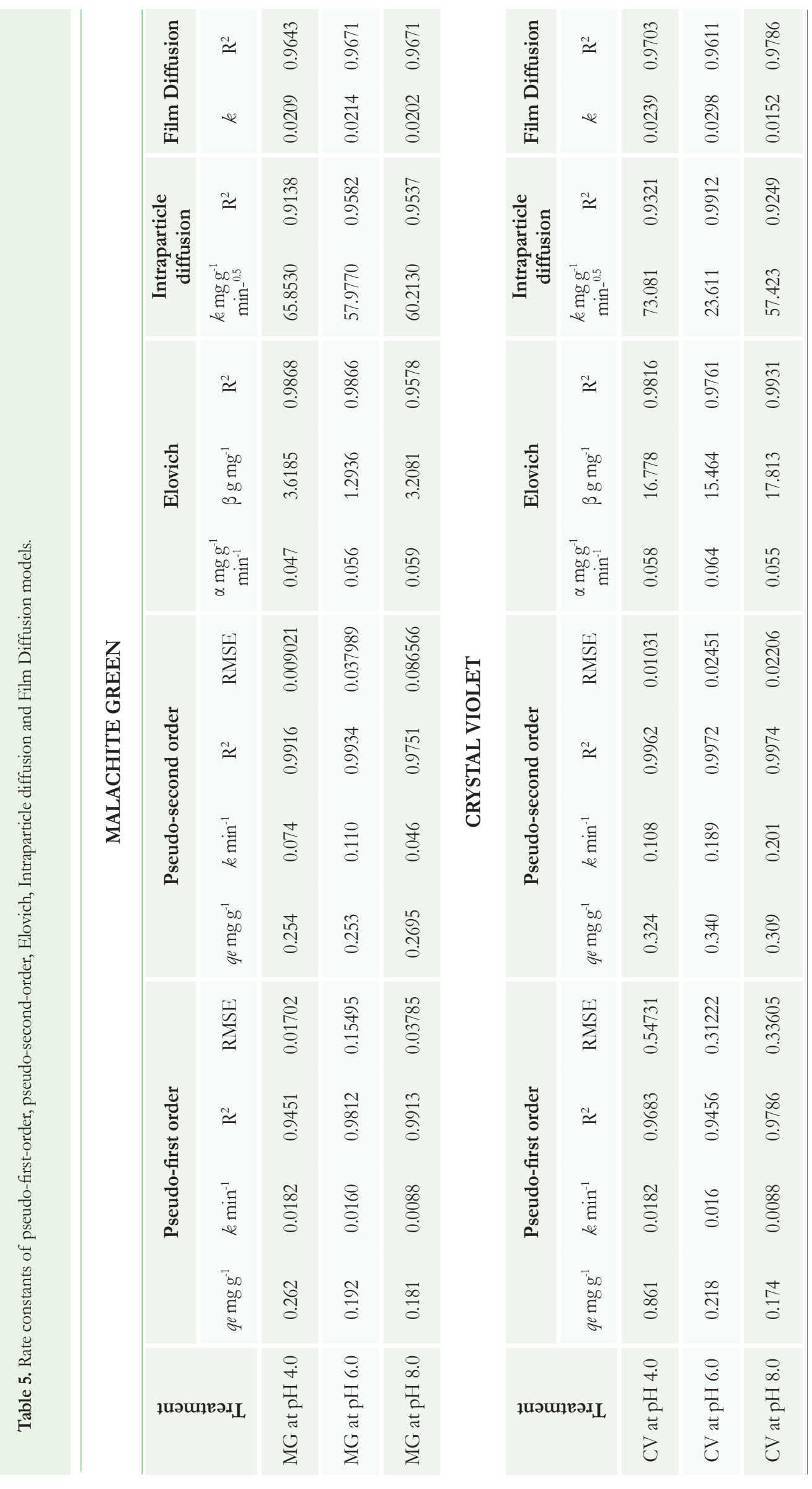


A

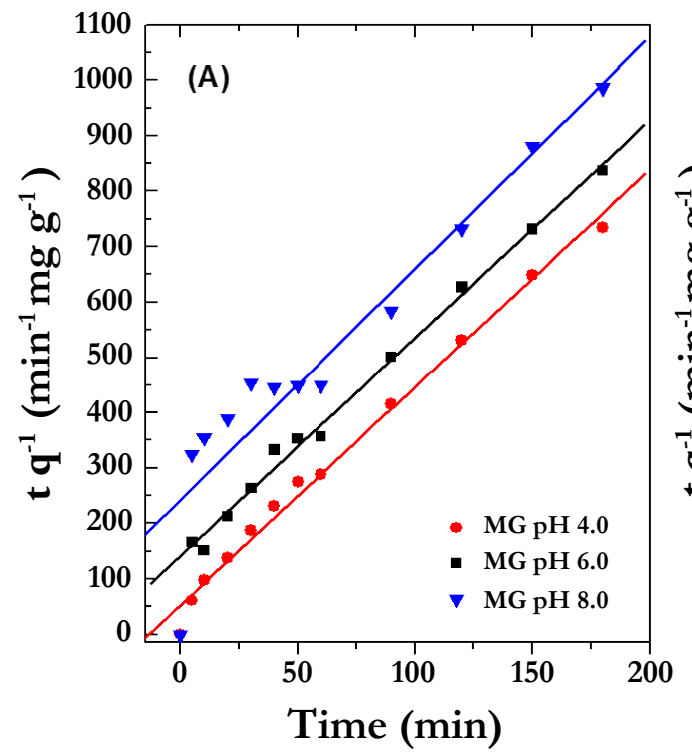

B

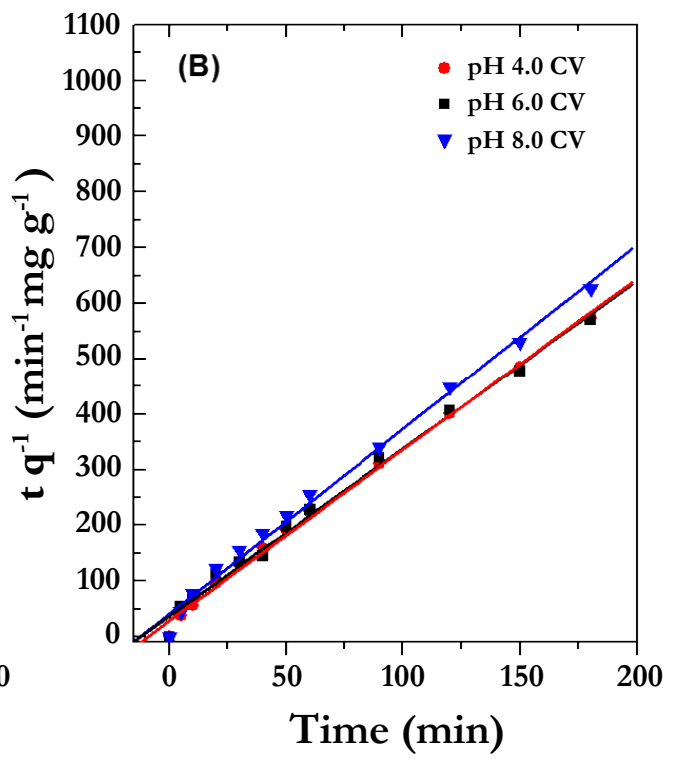

Fig. 4. Model of pseudo-second order in function of time for Malachite Green (A) and Crystal Violet (B) at $\mathrm{pH} 4.0,6.0$ and 8.0.

Regarding the pseudo-second order model, it was deduced that it is related to the adsorption capacity of the adsorbent and that the process may be taking place by chemisorptions. Some processes of biosorption of cationic dyes that are reported in the literature fit this model and are similar to those obtained in this work (Sun et al., 2008, Chowdhury et al., 2011, and Kumar \& Ahmad 2011).

Previous studies have demonstrated that in the model of pseudo-first order, the increase in the adsorption coefficient $(\mathrm{k})$ is proportional to the number of free sites on the surface of the adsorbent (Chergui et al., 2009). Therefore, the results of obtained $\mathrm{k}$ indicate that in the case of $\mathrm{MG}$, at lower $\mathrm{pH}$ (4.0 and 6.0), there is a higher number of free sites exposed on the surface which might attract the dye. The CV has some structural differences in relation to MG, such as the chlorine ion and a higher methylations number, which could change the way that the dye interaction takes place with the free sites exposed to the three $\mathrm{pHs}$ as the value of $\mathrm{k}$ was similar (Table 5), (Supplementary material A).

Authors like Dotto \& Pinto (2011), Dotto et al. (2013), and Morales-Alvarez et al. (2016) have demostrated that the Elocvich model helps support the adsorption by chemisorption. For this model, the adsorption rate decreases with time by the saturation of chitin and chitosan. For this reason, the initial rate of absorption $(\alpha)$ was lower at $\mathrm{pH} 4.0$ and 6.0 than $\mathrm{pH} 8.0$ for both dyes. In relation to the desorption coefficient $(\beta)$, the highest values were obtained for the $\mathrm{CV}$ at the three $\mathrm{pHs}$ which could indicate that $P$. ostreatus biomass has less affinity for the $\mathrm{CV}$ than for the $\mathrm{MG}$ whose desorption 
constants were not minor. This also could be related to the percentage of decolorization observed in the kinetics of removal with fungal biomass in which decolorization for CV was lower and longer than for MG (216 h) (Table 5).

Intraparticle diffusion model presented in Table $\mathbf{5}$ suggests that the existing linearity between $\mathrm{q}_{\mathrm{t}}$ and $\mathrm{t}^{1 / 2}$ is due to the intraparticle diffusion mechanism. According to the results, trend lines do not pass through the origin implying that the adsorption occurred by more than one mechanism and in two different phases (Gulnaz et al., 2006). It is possible that the first had been a superficial adsorption of the dye until reaching saturation. After that, the dye entered through the porosity of the wall fragments and it was adsorbed to the internal active sites (intraparticle diffusion), (Sahmoune \& Ouazene 2012). On the other hand, the bilinearity of the data has also been reported as an indicator of the presence of two different types of pores in the adsorbent (macropores and micropores), (Chergui et al., 2009). The process of inactivation of the fungal biomass by wet heat and pressure determines that the fungal wall is lysed, and fragments of different sizes are formed, in which different pore sizes may be present, leaving exposed multiple active sites (Table 5), (Supplementary material B).

The results obtained for the intraparticle diffusion model, could indicate that the dyes were transported to the surface of the biomass. Since this model is used to describe the flow of reactant (dye) through the surrounding fluid of the adsorbent surface (biomass), (Sen-Gupta \& Bhattacharyya 2011), (Table 5), (Supplementary Material C).

\section{Determination of index germination of Lactuca sativa}

The humid-chamber germination test (HCGT) and submerged germination test (SGT) exposed the response that has a biological vegetable model in the presence of the initial dyes and treated with viable biomass and non-viable biomass of P. ostreatus. With the data obtained the GI (\%) was calculated which served as a standard to evaluate the toxicity from a substance to a plant. When the values of this index are lower than $50 \%$, it is considered that the substance generates high phytotoxicity on the evaluated plant (Emino \& Warman 2004).

According to the results obtained for the MG and CV at $10 \mathrm{mg} \mathrm{L}^{-1}$ (Table 6), the two dyes untreated exert high phytotoxicity in seeds of $L$ sativa as it has a GR lower than $50 \%$ in the two methodologies evaluated (HCGT and SGT). When performing the treatment with VB from $P$. ostreatus at $100 \%$ (v/v) concentration, the GR increased above $50 \%$ for the two dyes in the two methodologies. This demonstrated that the combined mechanisms of adsorption and biotransformation lowered the adverse effect exerted by the dyes on the seed. However, they were not equal to the control with water (GR $100 \%$ ), which could be related to the presence of some intermediaries present after treatment; they do not absorb in the visible spectrum and are not evident in the residual color. For this reason, they could be part of the $2 \%$ of the residual decolorization obtained at 72 and $216 \mathrm{~h}$ of treatment.

When dilutions of the two dyes were made ( $50 \%$ and $25 \%$ ), an increment was detected in the GI being more evident for the CV in the submerged germination tests (SGT) than for those performed for humid-chamber germination tests (HCGT). Regarding the MG, the GR results in both concentrations tested were similar. 
Table 6. Seed germination Tests. GI: Germination Index (\%). HCGT: humid-chamber germination test. SGT: Submerged Germination Test. a*: Significantly different from control at $\mathrm{p}<0.05$ by one-way ANOVA

\section{MALACHITE GREEN}

\section{Treatments and controls}

Water

Initial MG at $10 \mathrm{mg} \mathrm{L-1}$ at $100 \%$ (v/v)

Final MG treated whit VB at $100 \%(\mathrm{v} / \mathrm{v})$

Final MG treated whit VB at $50 \%(\mathrm{v} / \mathrm{v})$

Final MG treated whit VB at $25 \%(\mathrm{v} / \mathrm{v})$

Final MG treated whit NVB at $100 \%$ (v/v)

Final MG treated whit NVB at $50 \%(\mathrm{v} / \mathrm{v})$

Final MG treated whit NVB at $25 \%(\mathrm{v} / \mathrm{v})$

\section{GI (\%) \\ (HCGT)}

$100 \pm 2.3$

$32.9 \pm 1.7 \mathrm{~b}$

$66.2 \pm 0.9$

$64 \pm 3.1$

$69 \pm 2.3$

$31 \pm 1.5$

$54 \pm 3.9$

$94 \pm 4.6$

$49 \pm 5.6$

GI (\%)

(SGT)

$69 \pm 1.4$

$61 \pm 3.8$

$68 \pm 1.4$

$46 \pm 1.1$
$100 \pm 3.8$

$41.8 \pm 2.5 a^{*}$

$48 \pm 1.6$

CRYSTAL VIOLET

\section{Treatments and controls}

GI $(\%)$

GI $(\%)$

(HCGT)

(SGT)

Water

$100 \pm 2.2$

$100 \pm 4.2$

Initial CV at $10 \mathrm{mg} \mathrm{L-1}$ at $100 \%$ (v/v)

$29.2 \pm 1.5 c$

$2.2 \pm 0.5 \mathrm{~d}$

Final CV treated whit VB at $100 \%(\mathrm{v} / \mathrm{v})$

$71 \pm 3.8$

$87 \pm 3.5$

Final CV treated whit VB at $50 \%(\mathrm{v} / \mathrm{v})$

$81 \pm 3.7$

$68 \pm 2.7$

Final CV treated whit VB at $25 \%(\mathrm{v} / \mathrm{v})$

Final CV treated whit NVB at $100 \%(\mathrm{v} / \mathrm{v})$

Final CV treated whit NVB at $50 \%(\mathrm{v} / \mathrm{v})$

Final CV treated whit NVB at $25 \%(\mathrm{v} / \mathrm{v})$
$86 \pm 4.4$

$98 \pm 4.2$

$13 \pm 0.6$

$2.1 \pm 0.3$

$22 \pm 1.3$

$9.2 \pm 1.1$

$35 \pm 1.9$

$14.1 \pm 1.2$ 
In tests using the post-treated dye solution with NVB at $100 \%$ was shown that GR were lower than, those obtained with VB $(31,13,46$, and 2.1 for MG and CV in HCGT and SGT), exerting a higher phytotoxic effect (Table 6). This could relate to the removal mechanism of $\mathrm{VB}$ which is of physical/chemical type and does not involve the enzymatic transformation. On the other hand, these results also help support the great complexity of $\mathrm{CV}$ and very probable its higher toxicity just as reported by other authors (Ayed et al. 2009, Parshetti et al. 2011).

Regarding dilutions of the dye solutions post-treated with NVB at 50 and $25 \%$, an increase in the GR was seen (higher in MG than in CV), when evaluated in humid-chamber germination test (HCGT), in contrast to what was observed in submerged germination test (SGT) were the values were lower, especially with the CV. When analyzing the results based on the methodologies used in most experiments, the values of GR for SGT were lower than the germination tests in humid chamber. This could be due to two factors (Table 6). On one side, the seeds used in a humid chamber were under a higher surface aeration than the seeds submerged. The increased surface aeration could affect the ATP production by respiratory pathway, as in the case of lettuce seeds, it has been reported low production of ATP by fermentative pathways (Hourmant \& Pradet 1981). Furthermore, Yazgan et al. (2008) report that excess moisture can decrease the active form of the phytochrome which acts directly on the germination of lettuce-seeds (Ojeda et al. 2012).

The toxic effect of MG on the elongation of the radicle has been previously reported by several authors using concentrations of $1000 \mathrm{mg} \mathrm{L}^{-1}$ and $100 \mathrm{mg} \mathrm{L}^{-1}$ in other plant models (Triticum aestivum, Ervum lens Linn, and Sorghum bicolor) (Ayed et al. 2010, and Shedbalkar \& Jadhav 2011). The same authors conducted biological treatments of the dyes and obtained a reduction in toxicity evidenced by the parameter of radicular elongation. For the $\mathrm{CV}$, they have also performed several studies showing its toxicity (Nouren \& Bhatti 2015).

Finally, considering that in the case of treatment with VB from P. ostreatus where GI was increased and raised to $50 \%$, it is possible to suggest that the toxicity generated by MG and CV is highly reduced in this treatment. Therefore, post-treated effluents could be used concentrated or diluted as irrigation water for plants other than for human or animal consumption (e.g. watering gardens and parks, or for walls and green roofs that handle hydroponic systems to keep moisture at appropriate levels to encourage the growth and maintenance of these green technologies). Moreover, we can use these solutions again for the manufacture of Gram stains and other specialized stains if the levels of conductivity and dissolved solids do not affect the quality of the stains.

\section{UVIVIS Spectrum}

To initial and post-treated dyes, UV/Vis spectrum were performed to show if changes in the maximum absorption peaks were present in the visible spectrum and if there were new peaks in the ultraviolet spectrum that could be related to the degradation intermediates (Figure 5). These studies also helped support some of the changes that occurred in germination studies with $L$. sativa seeds. 
A

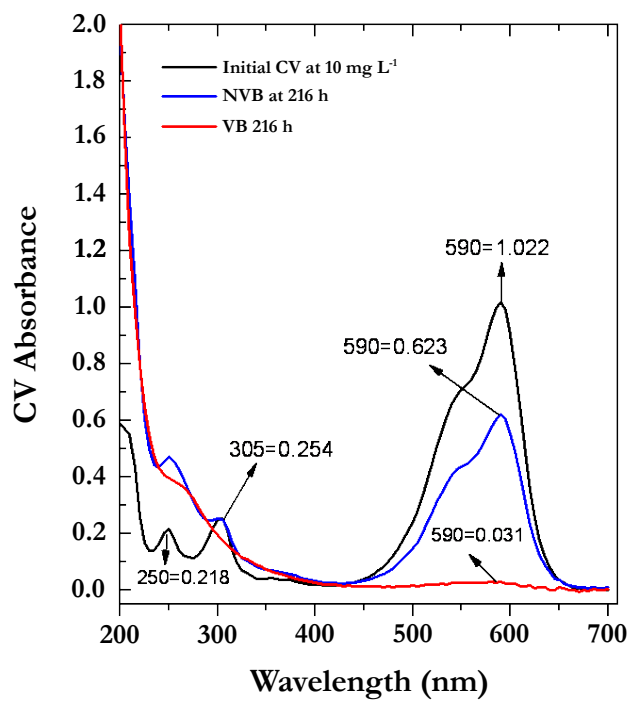

B

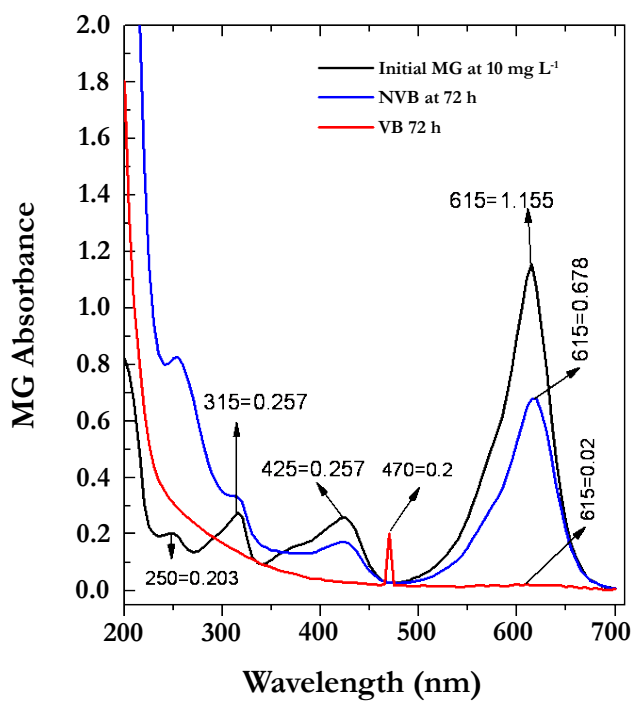

Fig. 5. UV/VIS Spectrum for Crystal Violet (A) and Malachite Green (B). Numbers observed in the peaks marked with arrows indicate the exact wavelength values (first number) and absorbance (second number)..

The CV without treatment showed a peak of maximum absorption at $\lambda=590 \mathrm{~nm}$ and two smaller peaks at $\lambda=305 \mathrm{~nm}$ and $\lambda=250 \mathrm{~nm}$ (Figure 5A) which are related to the chromophore group (central carbon or methane group bonded to three aryl groups) and aromatic rings attached to the dye. The maximum absorption peak for the MG was at $\lambda=615 \mathrm{~nm}$ with two additional signals at $\lambda=425 \mathrm{~nm}$ and $\lambda=315 \mathrm{~nm}$ (Figure 5B). Structurally the difference with the CV lies in several facts:

i) The solubilizing groups that each one possesses; where in the $\mathrm{CV}$ is the $\mathrm{C}^{-1}$ ion and in the $\mathrm{MG}$ the oxalate ion $\left(\mathrm{C}_{2} \mathrm{O}_{4}^{-2}\right)$.

ii) The number of substitutions; as the CV has three dimethyl groups as chromophore groups in comparison to the two that are in the MG; determining characteristics at the time of degradation. Since the dyes that have a higher number of substitutions present greater complexity and therefore, require longer processing times.

It was observed that VB at 216 and $72 \mathrm{~h}$, the peaks in the visible range disappeared for the two dyes without new signals in the UV spectrum. The disappearance could be related to the complete transformation process of the dyes in which aliphatic or dissolved intermediaries were left as sulfate, chloride, among others ions intermediaries. By contrast, with NVB we obtained a decreased area under the curve in the visible range for the two dyes, but was not a complete disappearance, which could be due to adsorption but not transformation. The UV signals tend to stay constant but with lower areas than those of the initial dye. 


\section{Conclusions}

This study demonstrated that two dyes belonging to the family of the triphenylmethane, a combined process of physical-chemical-enzymatic type, removed MG and CV by using $P$. ostreatus at laboratory scale. The results showed that the laccase activity and decolorization were mainly under the influence of parameters such as $\mathrm{pH}$, temperature, stirring rate, percentage of inoculum, and dyes concentration. According to the obtained kinetics of removal, using viable biomass increased significantly the decoloration and the presence of the dyes induced enzymatic activity; suggesting that laccase plays an important role in the attack to the structure of the dyes and therefore to their biodegradation. Additionally, with the UV/VIS spectrum, it was determined that in the experiments with viable biomass, there could have occurred a mechanism of biotransformation combined with an adsorption phenomena and in the case of using non-viable biomass, as expected, a phenomenon of adsorption without chemical alteration of the two dyes predominated. In addition, we observed the phytotoxic effect of the initial dyes with values of GI in seeds of $L$. sativa below $50 \%$. It also showed that when the seeds were placed against the treated dyes with VB, the GI increased, leaving open the possibility of reusability of the aqueous dye solutions (once treated); demonstrated as well that highly toxic compounds such as MG and CV can be degraded by P. ostreatus.

\section{Acknowledgments}

This research was funded by Grants, Project ID: 00004334 (Expresión a escala de laboratorio de las lacasas recombinantes de Pleurotus ostreatus y Ganoderma lucidum), and Project ID: 00004335 (Evaluación de Ganoderma lucidum, Pleurotus ostreatus y fotocatálisis con $\mathrm{TiO}_{2} / \mathrm{CuSO}_{4}$ para la remoción de colorantes trifenilmetánicos) from Pontificia Universidad Javeriana, Bogotá, D.C. Colombia Grupo de Biotecnología Ambiental e Industrial (GBAI). The funder had no role in study design, data collection and analysis, decision to publish, or preparation of the manuscript. Authors thank Adriana Rueda-Forero for English editing.

\section{Conflicts of Interest}

The authors have declared that no conflicting interests exists.

\section{References}

Abdallah R, Taha S. Biosorption of methylene blue from aqueous solution by nonviable Aspergillus fumigatus, Chemical Engineering Journal, 195-196: 69-76, 2012 doi: 10.1016/j.cej.2012.04.066

Aravindhan R, Fathima A, Selvamurugan M, Rao JR, Balachandran UN. Adsorption, desorption, and kinetic study on $\mathrm{Cr}$ (III) removal from aqueous solution using Bacillus subtilis biomas, Clean Techn Environ Policy, 14: 727-735, 2012

doi: 10.1007/s10098-011-0440-7

Ayed L, Chaieb K, Cheref A, Bakhrouf A. Biodegradation of triphenylmethane dye Malachite Green by Sphingomonas paucimobilis, World Journal of Microbiology and Biotechnology, 25: 705-711, 2009.

Ayed L, Chaieb K, Cheref A, Bakhrouf A. Biodegradation and decolorization of triphenylmethane dyes by Staphylococcus epidermidis, Desalination, 260: 137-146, 2010.

doi: 10.1016/j.desal.2010.04.052 
Casas N, Parella T, Vicent T, Caminal G, Sarrà M. Metabolites from the biodegradation of triphenylmethane dyes by Trametes versicolor or laccase, Chemosphere, 75: 1344-1349, 2009. doi: 10.1016/j.chemosphere.2009.02.029

Castillo-Carvajal LC, Pedroza-Rodríguez AM, Barragán-Huerta BE. Adsorption and biological removal of basic green 4 dye using white-rot fungi immobilized on Agave tequilana weber waste, Fresenius Environmental Bulletin, 22(8): 2334-2343, 2013.

Celis J, Sandoval M, Zagal E, Briones M. Effect of sewage sludge and salmon wastes applied to a Patagonian soil on lettuce (Lactuca Sativa L.) germination, Revista de la Ciencia del Suelo y Nutrición Vegetal, 6(3): 13-25, 2006.

doi: 110.4067/S0718-2791200600030000

Cheng W, Wang S-G, Lu L, Gong W-X, Liu X-IW, Gao B-Y, Zhang H-Y. Removal of malachite green $(M G)$ from aqueous solutions by native and heat-treated anaerobic granular sludge, Biochemical Engineering Journal, 39: 538-546, 2008.

doi: $10.1016 /$ j.bej.2007.10.016

Chergui A, Kerbachi R, Junter G-A. Biosorption of hexacyanoferrate (III) complex anion to dead biomass of the basidiomycete Pleurotus mutilus: Biosorbent characterization and batch experiments, Chemical Engineering Journal, 147: 150-160, 2009.

doi: $10.1016 /$ j.cej.2008.06.029

Chowdhury S, Chakraborty S, Saha P. Biosorption of basic Green 4 from aqueous solution by Ananas comosus (pineapple) leaf powder, Colloids and Surfaces B: Biointerfaces, 84: 520-527, 2011.

doi: 10.1016/j.colsurfb.2011.02.009

Dashtban M, Schraft H, Syed TA, Qin W. Fungal biodegradation and enzymatic modification of lignin, International Journal of Biochemistry and Molecular Biology, 1(1): 36-50, 2010.

Dotto GL, Moura JM, Cadaval TRS, Pinto LAA. Application of chitosan films for the removal of food dyes from aqueous solutions by adsorption, Chemical Engineering Journal, 214:8-16, 2013.

doi: 10.1016/j.cej.2012.10.027

Dotto GL, Pinto LAA. Adsorption of food dyes onto chitosan: Optimization process and kinetic, Carbohydrate Polymers, 84: 231-238, 2011.

doi: 10.1016/j.carbpol.2010.11.028

Emino ER, Warman PR. Biological assay for compost quality, Compost Science \& Utilization, 12(4): 342-348, 2004.

doi: 10.1080/1065657X.2004.10702203

Fischer AR, Werner P, Goss KU. Photodegradation of malachite green and malachite green carbinol under irradiation with different wavelength ranges, Chemosphere, 82 (2): $210-214$, 2011.

doi: 10.1016/j.chemosphere.2010.10.019

Gulnaz O, Kaya A, Dincer S. The reuse of dried activated sludge for adsorption of reactive dye, Journal of Hazardous Materials B, 134: 190-196, 2006.

doi: 10.1016/j.jhazmat.2005.10.050

Hai FI, Yamamoto K, Nakajima F, Fukushi K, Nghiem LD, Price WE, Jin B. Degradation of azo dye acid orange 7 in a membrane bioreactor by pellets and attached growth of Coriolus versicolour, Bioresource Technology, 141: 29-34, 2013.

doi: 10.1016/j.biortech.2013.02.020

Hourmant A, Pradet A. Oxidative phosphorylation in germinating lettuce seeds (Lactuca sativa) during the first hours of imbibition, Plant Physiology, 68: 631-635, 1981.

doi: 10.1104/pp.68.3.631 
Kang HW, Yang YH, Kim SW, Kim S, Ro H-S. Decolorization of triphenylmethane dyes by wild mushrooms, Biotechnology and Bioprocess Engineering, 19: 519-525, 2014.

doi: 10.1007/s12257-013-0663-z

Kaushik P, Malik A. Fungal dye decolourization: Recent advances and future potential, Environment International, 35: 127-141, 2009.

doi: 10.1016/j.envint.2008.05.010

Kumar R, Ahmad R. Biosorption of hazardous crystal violet dye from aqueous solution onto treated ginger waste (TGW), Desalination, 265: 112-118, 2011.

doi: 10.1016/j.desal.2010.07.040

Lyra ES, Moreira KA, Porto TS, Carneiro da Cunha MN, Paz Junior FB, Neto BB, LimaFilho JL, Cavalcanti MAQ, Converti A, Porto ALP. Decolorization of synthetic dyes by basidiomycetes isolated from woods of the Atlantic Forest (PE), Brazil, World Journal of Microbiology and Biotechnology, 25: 1499-1504, 2009.

doi: 10.1007/s11274-009-0034-2

Ma L, Zhuo R, Liu H, Yu D, Jiang M,Zhang X, Yang Y.Efficient decolorization and detoxification of the sulfonated azo dye Reactive Orange 16 and simulated textile wastewater containing Reactive Orange 16 by the white-rot fungus Ganoderma sp. En3 isolated from the forest of Tzu-chin Mountain in China, Biochemical Engineering Journal, 82: 1-9, 2014.

doi: 10.1016/j.bej.2013.10.015

Mahamadi C, Mawere E. Kinetic modeling of methylene blue and crystal violet dyes adsorption on alginate-fixed water hyacinth in single and binary systems, American Journal of Analytical Chemistry, 4: 17-24, 2013.

doi: $10.4236 /$ ajac.2013.410A3003

Miller G. Use of dinitrosalicilic acid reagent for determination of reducing sugar, Analytical Chemistry, 31(3): 426-428, 1959.

doi: $10.1021 / \mathrm{ac} 60147 \mathrm{a} 030$

Morales-Álvarez ED, Rivera-Hoyos CM, Chaparro-Núñez LE, Daza CE, Poutou-Piñales RA, Pedroza-Rodríguez AM. Decolorization and detoxification of Malachite Green by Ganoderma lucidum: Determination of key operating parameters and adsorption studies, Journal of Environmental Engineering, In Press, 2016.

doi: 10.1061/(ASCE)EE.1943-7870.0001180

Nouren S, Bhatti HN. Mechanistic study of degradation of basic violet 3 by Citrus limon peroxidase and phytotoxicity assessment of its degradation products, Biochemical Engineering Journal, 95: 9-19, 2015.

doi: 10.1016/j.bej.2014.11.021

Ojeda AD, Ligarreto GA, Martínez O. Effects of environmental factors on the morphometric characteristics of cultivated lettuce (Lactuca sativa L.), Agronomia Colombiana, 30(3): 351-358, 2012.

Oladoja NA, Aboluwoye CO, Oladimeji YB. Kinetics and isotherm studies on methylene blue adsorption onto ground palm kernel coat, Turkish Journal of Engeenering and Environmental Science, 32: 303-312, 2008.

Oplatowska M, Donnelly RF, Majithiya RJ, Kennedy DG, Elliott CT. The potential for human exposure, direct and indirect, to the suspected carcinogenic triphenylmethane dye Brilliant Green from green paper towels, Food and Chemical Toxicology, 49: 1870-1876, 2011. doi: 10.1016/j.fct.2011.05.005

Parshetti GK, Parshetti SG, Telke AA, Kalyani DC, Doong RA, Govindwar SP. Biodegradation of Crystal Violet by Agrobacterium radiobacter, Journal of Environmental Sciences, 23(8): 13841393, 2011. 
Patel H, Gupte A. Optimization of different culture conditions for enhanced laccase production and its purification from Tricholoma giganteum AGHP, Bioresources Bioprocessing, 3(11): 1 - 10, 2016.

doi: 10.1186/s40643-016-0088-6

Pedroza-Rodríguez AM, Rodríguez-Vázquez R. Optimization of C/N Ratio and Inducers for Wastewater Paper Industry Treatment Using Trametes versicolor Immobilized in Bubble Column Reactor, Journal of Micology, (Article ID 536721): 1-11, 2013. doi: $10.1155 / 2013 / 536721$

Przystaś W, Zabłocka-Godlewska E, Grabińska-Sota E. Biological removal of azo and Triphenylmethane dyes and toxicity of process by-products, Water Air Soil Pollution, 223: 1581-1592, 2012.

doi: 10.1007/s11270-011-0966-7

Puentes-Cárdenas IJ, Pedroza-Rodríguez AM, Navarrete-López M, Villegas-Garrido TL, Cristiani-Urbina E. Biosorption of trivalent chromium from aqueous solutions by Pleurotus ostreatus biomass, Environmental Engineering and Management Journal, 11(10): 1741-1752, 2012a.

Puentes-Cárdenas J, Florido-Cuellar A, Cardona-Bedoya J, Bohorquez-Echeverry P, Campos-Pinilla C, Gutiérrez-Romero V, Pedroza-Rodríguez A. Simultaneous decolorization and detoxification of black reactive 5 using $\mathrm{TiO}_{2}$ deposited over borosilicate glass, Universitas Scientiarum, 17(1): 53-63, 2012b.

doi: 10.11144/javeriana.SC17-1.sdad

Puentes-Cardenas IJ, Chávez-Camarillo CM, Cristiani-Urbina MC, Netzahualtl-Muñoz AR, Salcedo-Reyes JC, Pedroza-Rodríguez AM, Cristiani-Urbina E. Adsorptive Removal of acid Blue 80 Dye from Aqueous Solutions by $\mathrm{Cu}-\mathrm{TiO}_{2}$, Hindawi Publishing Corporatio Journal of Nanomaterials, 3542359, 2016.

doi: $10.1155 / 2016 / 3542359$

Quevedo-Hidalgo B, Narváez-Rincón PC, Pedroza-Rodríguez AM, Velásquez-Lozano ME. Production of lignocellulolytic enzymes from floriculture residues using Pleurotus ostreatus, Universitas Scientiarum, 20(1): 117-127, 2015.

doi: 10.11144/Javeriana.SC20-1.eple

Radha KV, Regupathi I, Arunagiri A, Murugesan T. Decolorization Studies of Synthetic Dyes Using Phanerochaete chrysosporium and their Kinetics, Process Biochemistry, 40: 3337-3345, 2005.

doi: 10.1016/j.procbio.2005.03.033

Rivera-Hoyos CM, Morales-Álvarez ED, Poutou-Piñales RA, Pedroza-Rodríguez AM, Rodríguez-Vázquez R, Delgado-Boada JM. Fungal laccases, Fungal Biology Reviens, 27(3-4): 67-82, 2013.

doi: 10.1016/j.fbr.2013.07.001

Rivera-Hoyos CM, Morales-Álvarez ED, Poveda-Cuevas SA, Reyes-Guzmán EA, PoutouPiñales RA, Reyes-Montaño EA, Pedroza-Rodríguez AM, Rodríguez-Vázquez R, CardozoBernal ÁM. Computational analysis and low-scale constitutive expression of laccases synthetic genes GILCC1 from Ganoderma lucidum and POXA 1B from Pleurotus ostreatus in Pichia pastoris, Plos One, 10(1): e0116524, 2015.

doi: 10.1371/journal.pone.0116524

Sáenz-Suárez H, Rivera-Hoyos CM, Morales-Álvarez ED, Poutou-Piñales RA, Sáenz-Moreno J, Pedroza-Rodríguez AM. Modelación computacional preliminar de la estructura 3D de dos lacasas fúngicas, Salud Arte y Cuidado, 7(1): 5-16, 2014.

Sahmoune MN, Ouazene N. Mass-transfer processes in the adsorption of cationic dye by sawdust, Environmental Progress \& Sustainable Energy, 32(4): 597-603, 2012.

doi: 10.1002/ep.10594 
Sen-Gupta S, Bhattacharyya KG. Kinetics of adsorption of metal ions on inorganic materials: A review, Advances in Colloid and Interface Science, 162: 39-58, 2011.

doi: 10.1016/j.cis.2010.12.004

Shedbalkar U, Jadhav JP. Detoxification of Malachite Green and textile industrial effluent by Penicillium ochrochloron, Biotechnology and Bioprocess Engineering, 16: 196-204, 2011. doi: 10.1007/s12257-010-0069-0

Sun X-F, Wang S-G, Liu X-W, Gong W-X, Bao N, Gao B-Y, Zhang H-Y. Biosorption of Malachite Green from aqueous solutions onto aerobic granules: Kinetic and equilibrium studies, Bioresource Technology, 99: 3475-3483, 2008. doi: 10.1016/j.biortech.2007.07.055

Thetford D. Triphenylmethane and related dyes, in, (Eds). Van Nostrand's Scientific Encyclopedia, Wiley Online Library 2006.

Tinoco R, Pickard MA, Vazquez-Duhalt R. Kinetic differences of purified laccases from six Pleurotus ostreatus strains, Letters in Applied Microbiology, 32: 331-335, 2001. doi: 10.1046/j.1472-765X.2001.00913.x

Vasdev K. Decolorization of triphenylmethane dyes by six white-rot fungi isolated from nature, Bioremediation \& Biodegradation, 2(5): 128, 2011.

doi: $10.4172 / 2155-6199.1000128$

Yazgan S, Ayas S, Demirtas C, Büyükcangaz H, Candogan BN. Deficit irrigation effects on lettuce (Lactuca sativa var. Olenka) yield in unheated greenhouse condition, Journal of Food, Agriculture \& Environment, 6(2): 357-361, 2008.

Zhang J, Zhang J. The filamentous fungal pellet and forces driving its formation, Critical Reviews in Biotechnology 18: 1-12, 2015

doi: $10.3109 / 07388551.2015 .1084262$

Zucconi F, Monaco A, Forte M, De Bertoldi M. Phytotoxins during the stabilization of organic matter, in Gasser, (Eds). Composting of Agricultural and Other Wastes. Elsevier, London, UK, 1985. 
Eliminación parcial y desintoxicación de Verde Malaquita y Cristal Violeta del laboratorio con agua contaminada artificialmente por Pleurotus ostreatus

Resumen. Los colorantes trifenilmetánicos Verde Malaquita (MG) y Crystal Violeta (CV) son catiónicos y al ser vertidos se mezclan con aguas residuales domésticas, incrementando, entre otros, la demanda química y biológica de oxígeno; pudiendo causar toxicidad aguda en diferentes niveles tróficos. En este estudio se encontró que los parámetros $\mathrm{pH}(4,5$ y 6,0$)$, temperatura $\left(25\right.$ y $\left.30^{\circ} \mathrm{C}\right)$, velocidad de agitación (120 r.p.m.), porcentaje de inóculo $(2 \% \mathrm{v} / \mathrm{v})$ y concentración de colorante (20 y $\left.10 \mathrm{mgL}^{-1}\right)$, presentaron un efecto significativo $(\mathrm{p}<0.05)$ para favorecer la remoción (decoloración) de MG y CV, así como la actividad lacasa (54,76 \pm 8,91 y 30,59 $\pm 2,89 \mathrm{UL}^{-1}$ respectivamente) al utilizar biomasa viable de $P$. ostreatus. En los estudios de adsorción se evidenció que $\mathrm{pH}$ ácidos favorecen la adsorción de ambos colorantes y que el modelo de Pseudo-segundo orden describe mejor el fenómeno de quimisorción. Finalmente los índices de germinación (IG) empleando semillas de Lactuca sativa, para los colorantes iniciales fueron $<50 \%$; demostrando su efecto fitotóxico elevado. Cuando las soluciones de colorantes fueron tratadas con biomasa viable, el IG aumentó, dejando abierta la puerta para la realización de investigaciones futuras con la intensión de determinar si las soluciones acuosas, postratadas con $P$. ostreatus, pueden ser utilizadas en tratamientos que generen aguas menos tóxicas y que estas puedan ser empleadas en otros procesos que no requieran agua potable.

Palabras clave: Pleurotus ostreatus; Verde Malaquita; Crystal Violeta; decoloración y adsorción.

Extração e desintoxicaçáo de Verde Malaquita e Cristal Violeta de água contaminada artificialmente em laboratório por Pleurotus ostreatus.

Resumen. Os corantes de tipo trifenilmetano Verde Malaquita (VM) e Cristal Violeta (CV) são corantes catiônicos e se misturam com águas residuais domésticas quando descartadas; aumentando, entre outros, as demandas químicas e biológicas de oxigênio, podendo causar toxicidade aguda em diferentes níveis tróficos. Promoveu-se a remoção (descoloração) de VM e CV, e atividade da lacase $\left(54.8 \pm 8.9\right.$ e $30.6 \pm 2.9 \mathrm{UL}^{-1}$ respectivamente) utilizando como parâmetros necessários para a biomassa viável de $P$. ostreatus como pH $(4,5$ e 6,0$)$, temperatura $\left(25\right.$ a $\left.30^{\circ} \mathrm{C}\right)$, velocidade de agitação (120 RPM), porcentagem de inócuo $(2 \% \mathrm{v} / \mathrm{v})$, e concentração de corante $\left(20\right.$ e $\left.10 \mathrm{mg} \mathrm{L}^{-1}\right)$. Em estudos de absorção, se demonstrou que um $\mathrm{pH}$ mais ácido favorece a absorção de ambos corantes e o modelo de pseudo-segunda ordem descreve melhor o fenômeno da absorção. Finalmente, o índice de germinação (IG), utilizando sementes de Lactuca sativa para as soluções iniciais dos corantes, foi $<50 \%$; demonstrando assim seu alto efeito fitotóxico. Quando as soluções de corante foram tratadas com a biomassa viável, o IG aumentou, deixando em aberto a possibilidade de realizar futuras investigações para determinar se as soluções aquosas, tratadas com $P$. ostreatus, poderiam ser utilizadas em tratamentos que gerem águas menos tóxicas, que poderia ser utilizada em processos que não requerem água potável.

Palabras clave: Pleurotus ostreatus; Verde Malaquita; Cristal Violeta; descoloração e absorção.

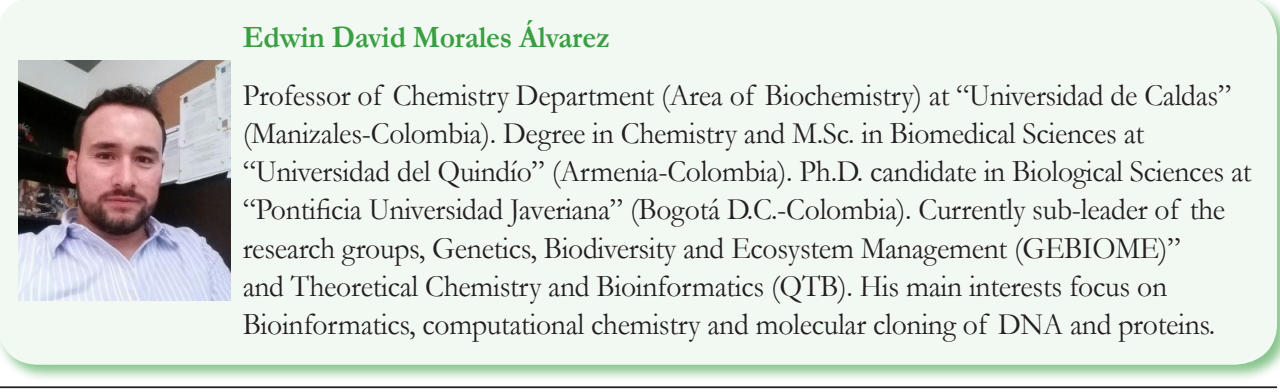



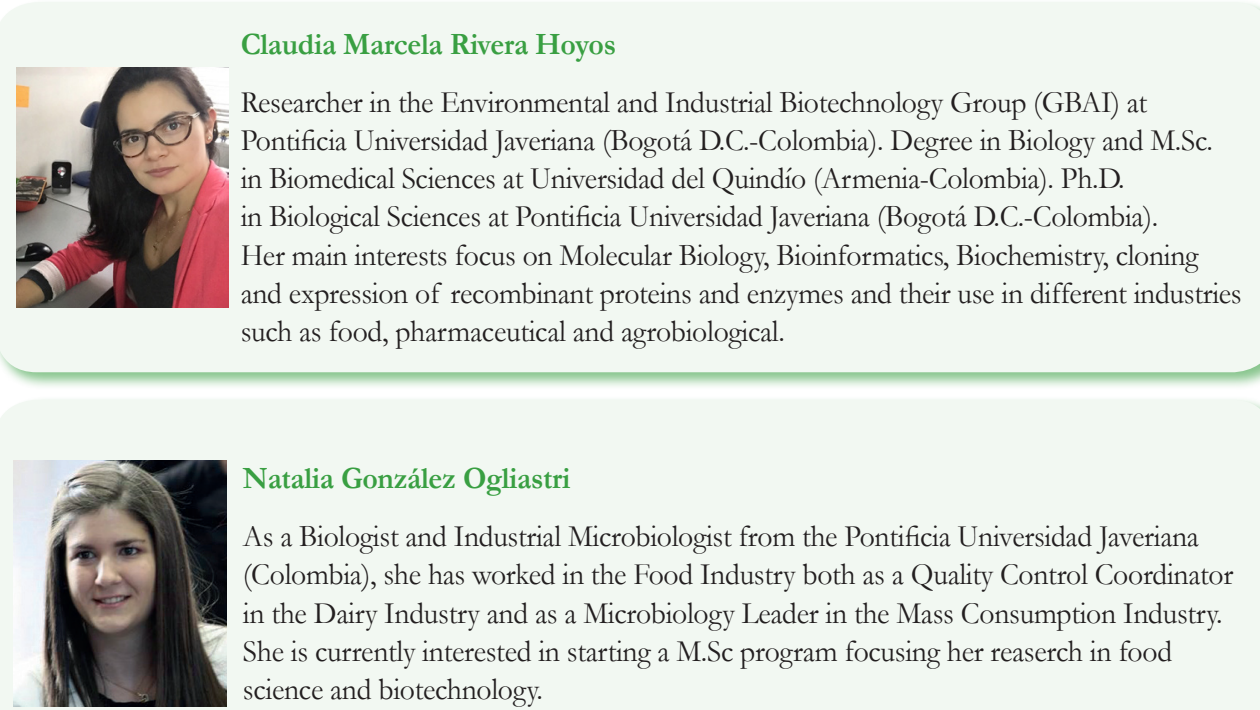

Natalia González Ogliastri

As a Biologist and Industrial Microbiologist from the Pontificia Universidad Javeriana (Colombia), she has worked in the Food Industry both as a Quality Control Coordinator in the Dairy Industry and as a Microbiology Leader in the Mass Consumption Industry. She is currently interested in starting a M.Sc program focusing her reaserch in food science and biotechnology.

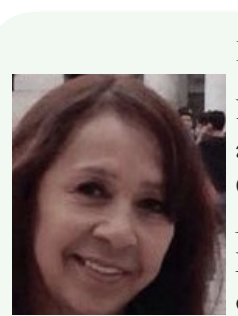

Refugio Rodríguez-Vázquez

Professor of Biotechnology and Bioengineering Department, and PhD Nanosciences and Nanotechnology Program, at CINVESTAV-IPN, Mexico. She has a PhD from Colorado State University, Co, E.U.A. (1993). Regular Member of the Mexican Academy of Sciences (2000-actual). Member of the National System of Researchers Level III, (2016-2019). Her main research interest is in Bioremediation of soil and water contaminated with organic pollutants, with agroindustrial residues; and the applications of combined bio-nano technologies.

\section{Raúl A. Poutou-Piñales}

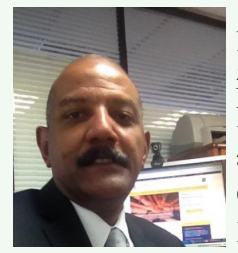

Professor at Microbiology Department, COLCIENCIAS Senior researcher. Technician in Analytical Chemistry at Chemistry Institute "Mártires de Girón" and Degree in Biochemistry at "Universidad de la Habana" (Habana-Cuba)", M.Sc. in Microbiology and Ph.D. in Biological Sciences at "Pontificia Universidad Javeriana" (Bogotá-Colombia). Currently leader of Environmental and Industrial Biotechnology Group (GBAI). His main research interests focus on expression of recombinant proteins and enzymes and their use in different industries such as food, pharmaceutical and agrobiological.

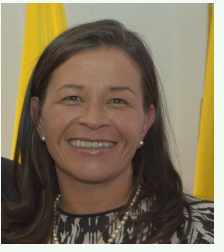

Aura Marina Pedroza

Professor of Microbiology Department. COLCIENCIAS Senior researcher. Degree in Bacteriology and M.Sc. in Microbiology at "Pontificia Universidad Javeriana" (Colombia), Ph.D. in Biological Sciences at "Centro de Investigaciones y estudios Avanzados CINVESTAV” (México D.F.). Currently researcher at Environmental and Industrial Biotechnology Group (GBAI). One of her main research interests focus on unconventional biological systems and advanced oxidation processes for the removal of pollutants in waste water.

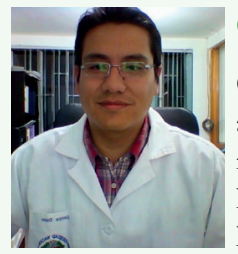

Carlos Daza

Chemist, Doctor of Chemical Sciences. Associate Professor of Chemistry Department at Universidad Nacional de Colombia (Bogotá D.C.-Colombia). COLCIENCIAS senior researcher. He works in the area of chemical adsorbents and catalysts for reactions with heterogeneous beneficial impact on the environment. His interest focuses on obtaining low-cost solid using agro-industrial waste and minerals as precursors. 